Summer 2013

\title{
Leaving Private Practice: How Organizational Context, Time Pressures, and Structural Inflexibilities Shape Departures from Private Law Practice
}

\author{
Fiona M. Kay \\ Queen's University, kayf@queens.ca \\ Stacey Alarie \\ Queens University,7sa18@queens.ca \\ Jones Adjei \\ Queens University,6jka@queens.ca
}

Follow this and additional works at: https://www.repository.law.indiana.edu/ijgls

Part of the Labor and Employment Law Commons, Law and Gender Commons, Law and Society Commons, and the Legal Profession Commons

\section{Recommended Citation}

Kay, Fiona M.; Alarie, Stacey; and Adjei, Jones (2013) "Leaving Private Practice: How Organizational Context, Time Pressures, and Structural Inflexibilities Shape Departures from Private Law Practice," Indiana Journal of Global Legal Studies: Vol. 20 : Iss. 2 , Article 22.

Available at: https://www.repository.law.indiana.edu/ijgls/vol20/iss2/22

This Symposium is brought to you for free and open access by the Law School Journals at Digital Repository @ Maurer Law. It has been accepted for inclusion in Indiana Journal of Global Legal Studies by an authorized editor of Digital Repository @ Maurer Law. For more information, please contact rvaughan@indiana.edu. 


\title{
Leaving Private Practice: How Organizational Context, Time Pressures, and Structural Inflexibilities Shape Departures from Private Law Practice
}

\author{
FIONA M. KAY, STACEY AlaRIE, \& JONES ADJEI*
}

\begin{abstract}
Numerous studies document women's overrepresentation among those leaving the profession of law. Although research has documented high turnover among women lawyers, particularly from private practice, only a handful of studies have explored the factors precipitating the decision to leave. The main causal factors identified to date include difficulties associated with combining family life and law practice and problems of discrimination and blocked career advancement. In this paper, we analyze data from a longitudinal study of nearly 1,600 Canadian lawyers, surveyed across a twenty-year period. Using survival models to estimate the timing of transitions out of private practice, we examine factors precipitating exits from private practice. We find that women are leaving private practice at higher rates than men. These departures appear to be largely the consequence of organizational structures and a practice culture that remain resistant to flexible schedules, time gaps between jobs, and parental and other leaves. Yet, the careers of contemporary lawyers appear to be characterized by more job changes, discontinuity, and movement between sectors of practice than is commonly assumed. Our paper moves discussion beyond the

* Fiona Kay is a Professor of Sociology at Queen's University. Stacey Alarie and Jones Adjei are Ph.D candidates in the Sociology Department at Queen's University. This study was funded by research grants from the Law School Admission Council (LSAC) and the Social Sciences and Humanities Research Council of Canada (SSHRC) and with the cooperation of the Law Society of Upper Canada. The opinions contained in this paper are those of the authors and do not necessarily reflect the position or policy of LSAC or the Law Society. We would like to thank Carroll Seron for her helpful and constructive comments on an earlier draft of this paper. We also wish to acknowledge the useful feedback offered by participants in the Law, Gender and Equality Seminar at the Faculty of Law, Queen's University. An earlier version of this paper was presented at the 2012 Annual Meeting of the Law \& Society Association in Honolulu, Hawaii.
\end{abstract}

Indiana Journal of Global Legal Studies Vol. 20, Issue 2 (2013)

(C) Indiana University Maurer School of Law 
work-family debate and motherhood, to examine the broader issues of institutional constraints on careers of both men and women in law and policy initiatives to encourage retention of legal talent in private practice.

\section{INTRODUCTION}

Numerous studies have documented that, after investing in undergraduate and law school studies and establishing careers in law practice, women are leaving the legal profession at higher rates than men. ${ }^{1}$ Attrition is costly for both law firms and the women lawyers who leave. Employers incur a significant cost in the recruitment and development of junior associates, and they strive to retain the legal talent they have. ${ }^{2}$ Turnover also creates high costs due to missed contributions of experienced firm lawyers, instability of departments or teams, disruptions to trusted relations between firm lawyers and clients, and loss of proficiency. ${ }^{3}$ The cost of losing lawyers from a firm is particularly severe if a component of their knowledge was strongly firm-specific, such as deep tacit knowledge about the firm's culture and

1. See generally JoHn HaGan \& FIONA Kay, Gender IN Practice: A STUdY of LAWYERS' LIVES (1995); Joan Brockman, Leaving the Practice of Law: The Wherefores and the Whys, 32 Alta. L. REv. 116 (1994); Kathleen E. Hull \& Robert L. Nelson, Assimilation, Choice, or Constraint? Testing Theories of Gender Differences in the Careers of Lawyers, 79 SOC. ForCes 229 (2000); Fiona M. Kay \& John Hagan, Cultivating Clients in the Competition for Partnership: Gender and the Organizational Restructuring of Law Firms in the 1990s, 33 LAW \& Soc'Y REv. 517 (1999); Mary C. Noonan \& Mary E. Corcoran, The Mommy Track and Partnership: Temporary Delay or Dead End?, 596 ANNALS AM. ACAD. PoL. \& Soc. ScI. 130 (2004); Paula A. Patton, Women Lawyers, Their Status, Influence, and Retention in the Legal Profession, 11 WM. \& MARY J. WOMEN. \& L. 173 (2005); Stephen J. Spurr \& Glenn T. Sueyoshi, Turnover and Promotion of Lawyers: An Inquiry into Gender Differences, 29 J. HUM. ResouRCes 813 (1994). For works collecting authorities, see generally Jean E. Wallace, Explaining Why Lawyers Want to Leave the Practice of Law, in LEGAL PROFESSIONS: WORK, STRUCTURE AND ORGANIZATION 117 (Jerry Van Hoy ed., 2001); Fiona M. Kay, Flight from Law: A Competing Risks Model of Departures from Law Firms, 31 LAW \& Soc'Y REV. 301 (1997); Nancy J. Reichman \& Joyce S. Sterling, Recasting the Brass Ring: Deconstructing and Reconstructing Workplace Opportunities for Women Lawyers, 29 CAP. U. L. REV. 923 (2002).

2. See Paul T.Y. Preenen et al., Managing Voluntary Turnover Through Challenging Assignments, 36 GRouP \& ORG. MGMT. 308, 309 (2011); Judith G. Proudfoot et al., Cognitive-Behavioural Training to Change Attributional Style Improves Employee Well-Being, Job Satisfaction, Productivity, and Turnover, 46 PERSONALITY \& INDIVIDUAL DIFFERENCES 147, 147 (2009).

3. See James M. Baron, Michael T. Hannan \& M. Diane Burton, Labor Pains: Change in Organizational Models and Employee Turnover in Young, High-Tech Firms, 106 AMER. J. OF SOCIOLOGY 1008 (2001). 
business acumen, because this knowledge is difficult to rebuild or replace. ${ }^{4}$

For lawyers, leaving a law firm also carries personal costs. Law graduates invest years in higher education and certification and often graduate with a sizeable student debt load. ${ }^{5}$ Individuals who leave law practice after years of study and professional training make a significant change in their career path from their initial aspirations. Even turnover within the legal profession, across firms or between sectors of practice, disrupts individuals' lives in the short term and may have long-term costs in regard to earnings and career advancement. ${ }^{6}$ For women, job turnover may be particularly damaging. Women lawyers leaving private law practice, for example, may find it difficult to "opt back in"7 at commensurate job levels. ${ }^{8}$ These barriers to reentry further perpetuate and exacerbate gender inequalities. ${ }^{9}$

To date, research has focused narrowly on dissatisfaction with promotion opportunities and motherhood and the issue of work-life

4. See K. Michele Kacmar et al., Sure Everyone Can Be Replaced . . But at What Cost? Turnover as a Predictor of Unit-Level Performance, 49 ACAD. MGMT. J. 133, 135 (2006). But see Deepak Somaya et al., Gone but Not Lost: The Different Performance Impacts of Employee Mobility Between Cooperators Versus Competitors, 51 ACAD. MGMT. J. 936 (2008) (finding that employee lost to "cooperators," such as clients, may produce positive benefits for the employer). See generally John Benson \& Michelle Brown, Knowledge Workers: What Keeps Them Committed; What Turns Them Away, 21 WoRK EMP. \& SOC'Y 121 (2007) (considering various methods of employee retention).

5. See generally LINDA R. HIRSHMAN, GET TO WORK: A MANIFESTO FOR WOMEN OF THE WORLD (2006) (discussing the extent to which women invest in education, yet do not reap the benefits thereof).

6. See Jean McKenzie Lieper, BAR Codes: WoMEN IN THE LEgal Profession 143-76 (2006); Joan Brockman, GENDER IN THE LEGAL PROFESSION: FITTING IN OR BREAKING THE Mould 196-215 (2001); Mary C. Noonan \& Mary E. Corcoran, The Mommy Track and Partnership: Temporary Delay or Dead End? 596 ANNALS AMER. ACAD. POL. SOC. SCI. 130 (2004).

7. See Lisa Belkin, The Opt-Out Revolution N.Y. Times MAG., Oct. 26, 2003, at 42-47, 58, 85-86.

8. See Brockman, supra note 1, at 152; See generally Final Report-Retention of Women in Private Practice Working Group, THE LAW SOCIETY OF UPPER CANADA (May 2008), available at http://www.lsuc.on.ca/media/convmay08_retention_of_women_consulta tion.pdf.

9. See generally Phyldis Moen \& Patricia Roehling, The Career Mystique: CRACKS IN THE AMERICAN DREAM (2005); Shoba V. Arun et al., The Effect of Career Breaks on the Working Lives of Women, 10 FEMINIST ECON. 65 (2004) (examining the penalties faced by women who take breaks from employment); Michelle J. Budig \& Paula England, The Wage Penalty for Motherhood, 66 AM. SoC. REV. 204 (2001) (examining the negative effect of motherhood on wage rates); Diane H. Felmlee, Causes and Consequences of Women's Employment Discontinuity, 1967-1973, 22 WORK \& OCCUPATIONS 167 (1995) (finding that breaks from employment negatively impact the wages of young white women). 
balance as the primary reasons why women lawyers leave their job. ${ }^{10}$ Yet, a far more extensive range of factors influence whether women change jobs, leave law practice, or stay with their first employer after admission to the Bar. ${ }^{11}$ Broader consideration of the organizational and environmental factors shaping women lawyers' employment opportunities and job-changing behavior is lacking in the literature. ${ }^{12}$ This paper starts to fill this gap by identifying and testing for the effects of several possible theoretical mechanisms that may be salient to job turnover. Using a sample of lawyers who started their careers in private practice, either in law firms or as solo practitioners, we examine the following research questions: (1) Do most lawyers launching their careers in private practice remain in private practice across the span of their careers or is there significant attrition from private practice?; (2) What factors prompt lawyers to leave private practice?; and (3) What policies might help to retain legal talent and reduce turnover in private practice?

\section{THEORETICAL EXPLANATIONS}

\section{A. Job Satisfaction and Turnover}

One of the most pervasive explanations of turnover draws attention to the experience of professional work, particularly subjective assessments and organizational attachment fostered through work. As

10. Jean McKenzie Leiper, Bar Codes: Women in the Legal Profession 47 (2006) (citing Mary Jane Mossman, Gender Bias and the Legal Profession: Challenges and

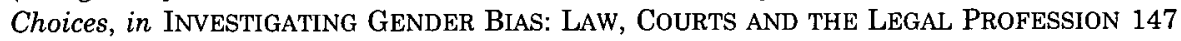
(Joan Brockman \& Dorothy Chunn eds., 1993)), as an example of a singular focus on work/life balance); Joan C. Williams, Legal Professions and Job Demands: Implications for Work/Life Balance, in WORK \& FAMILY ENCYCLOPEDIA (Stephen Sweet \& Judi Casey eds., 2007), available at https://workfamily.sas.upenn.edu/wfrn-repo/object/ps3xp23bf1p07d8x; Deborah L. Rhode, Gender and the Profession: The No-Problem Problem, 30 HofsTRA L. REV. 1001 (2002); DeeAnn Wenk \& Rachel A. Rosenfeld, Women's Employment Exit and Reentry: Job-Leaving Reasons and Their Consequences, 11 RES. SOC. STRATIFICATION \& MoBILITY 127, 129 (1992). But see Joan Brockman, An Update on Gender and Diversity in the Legal Profession in Alberta, 1991-2003, in CALLING FOR CHANGE: WoMEN, LAW, AND THE LeGal Profession 237 (Elizabeth Sheehy \& Sheila McIntyre eds., 2006) (exploring sexual harassment among other factors that drive women from the legal workforce).

11. See Fiona M. Kay, Flight From Law: A Competing Risks Model of Departures from Law Firms, 31 L. \& Soc. REv. 327-330 (1997); Rhode, supra note 10; Brockman, supra note 1 , at 139 ; D. N. Laband \& B. F. Lentz, SEX Discrimination IN THE LEGAL Profession (1995); Fiona M. Kay \& John Hagan, Building Trust: Social Capital, Distributive Justice, and Loyalty to the Firm, 28 L. \& Soc. INQUIRY 483 (2003).

12. Christine Percheski, Opting Out? Cohort Differences in Professional Women's Employment Rates from 1960 to 2005, 73 AM. SoC. REV. 497, $501-02$ (2008). 
R. P. Steel notes, "no other single domain of work has had as much influence on turnover research as attitude theory."13 Attitude theory argues that job satisfaction mediates the relationship between job and organizational attributes (e.g. earnings, nature of the work, advancement opportunities, and coworker relations) and turnover. ${ }^{14}$ The general claim is that dissatisfaction with one's job triggers thoughts about leaving the organization. ${ }^{15}$ Numerous studies find support for this theory, demonstrating job satisfaction to be an important factor in predicting employee retention across a range of professions. ${ }^{16}$ So, are men and women equally satisfied in law practice?

Several studies of lawyers find that although women report overall job satisfaction equal to that of men, women report being less satisfied with specific aspects of their work. ${ }^{17}$ Women lawyers appear less satisfied with such aspects as compensation, job opportunities, ${ }^{18}$ job setting, and promotion prospects. ${ }^{19}$ However, such factors are important

13. Robert P. Steel, Turnover Theory at the Empirical Interface: Problems of Fit and Function, 27 ACAD. MGMT. REV. 346, 346 (2002).

14. Rodger W. Griffeth et al., A Meta-Analysis of Antecedents and Correlates of Employee Turnover: Update, Moderator Tests, and Research Implications for the Next Millennium, 26 J. MGMT. 463, 479 (2000).

15. Kathleen Bentein et al., The Role of Change in the Relationship Between Commitment and Turnover: A Latent Growth Modeling Approach, 90 J. APPLIED PSYCHOL. 468, 468 (2005); Wendy R. Boswell et al., The Relationship Between Employee Job Change and Job Satisfaction: The Honeymoon-Hangover Effect, 90 J. APPLIED PSYCHOL. 882, 882 (2005).

16. Michàl E. Mor Barak et al., Antecedents to Retention and Turnover Among Child Welfare, Social Work, and Other Human Service Employees: What Can We Learn from Past Research? A Review and Metanalysis, 75 Soc. SERV. REv. 625, 631 (2001); John L. Cotton \& Jeffrey M. Tuttle, Employee Turnover: A Meta-Analysis and Review with Implications for Research, 11 ACAD. MGMT. REV. 55, 60 (1986); Griffeth et al., supra note 14, at 475; Eric G. Lambert et al., An Exploratory Examination of the Consequences of Burnout in Terms of Life Satisfaction, Turnover Intent, and Absenteeism Among Private Correctional Staff, 90 PRISON J. 94, 100-01 (2010); W. H. Mobley et al., Review and Conceptual Analysis of the Employee Turnover Process, 86 PSYCHOL. BULL. 493, 493 (1979); Nathan P. Podsakoff et al., Differential Challenge Stressor-Hindrance Stressor Relationships with Job Attitudes, Turnover Intentions, Turnover, and Withdrawal Behavior: A Meta-Analysis, 92 J. APPLIED PsyCHOL. 438, 439-40 (2007); Joseph C. Rode et al., The Effect of Work/Family Conflict on Intention to Quit: The Mediating Roles of Job and Life Satisfaction, 2 APPLIED RES. QUALITY LIFE 65, 77 (2007).

17. Kathleen E. Hull, The Paradox of the Contented Female Lawyer, 33 LAW \& Soc'Y REV. 687, 689 (1999); Nancy J. Reichman \& Joyce S. Sterling, Sticky Floors, Broken Steps, and Concrete Ceilings in Legal Careers, 14 TEX. J. WOMEN \& L. 27, 46 (2004).

18. Reichman \& Sterling, supra note 1, at 46 \& n. 83.

19. RONIT DiNOVITZER ET AL., AFTER THE JD: FIRST RESUlTS OF A NATIONAL STUDY OF LEGAL CAREERS 58 (2004). See generally Ronit Dinovitzer et al., The Differential Valuation of Women's Work: A New Look at the Gender Gap in Lawyers' Incomes, 88 SoC. FORCES 819 (2009) (identifying the above as mechanisms which partially contribute to the gender wage gap in the legal profession). 
in creating a work environment that induces workers to remain employed at the organization. ${ }^{20}$ Failure to satisfy junior lawyers' aspirations via resources, assignments, and advancement possibilities encourages lawyers to consider leaving their workplace. ${ }^{21}$ Weak prospects of being promoted, in particular, appear to be a key consideration in the decision by junior lawyers to quit a firm or transfer to another firm or employer. ${ }^{22}$ Women professionals generally receive a smaller share of workplace rewards, including promotions. ${ }^{23}$ For example, in a study of 2,587 lawyers from two cohorts (1969-1973 and 1980-1983) of U.S. lawyers in Chicago and New York, Stephen Spurr and Glenn Sueyoshi found that "women [lawyers] are considerably less likely to be promoted and slightly more likely to leave the firm" than men. ${ }^{24}$ Similarly, Joan Brockman's study of British Columbian lawyers revealed ' [c] c]areer advancement' and 'attaining partnership' were most frequently mentioned by lawyers of both genders as ... area[s] in which women are discriminated against." 25 As Nicola Patterson and Sharon Maven note, "it is perhaps unsurprising that women are leaving corporate employment in increasing numbers as their need for challenge, achievement and status is left unfulfilled."26

Although much of the literature on job satisfaction and turnover has emphasized the importance of promotion opportunities to secure retention, clearly other job resources can play a motivational role by increasing lawyers' learning and development and fostering a dynamic work environment. ${ }^{27}$ Job resources, such as social support offered by

20. See Ishak Saporta \& Moshe Farjoun, The Relationship Between Actual Promotion and Turnover Among Professional and Managerial-Administrative Occupational Groups, 30 WORK \& OCCUPATIONS 255, 255 (2003).

21. Cf. Deborah J. Armstrong et al., Advancement, Voluntary Turnover and Women in IT: A Cognitive Study of Work-Family Conflict, 44 INFO. \& MGMT. 142 (2007) (summarizing a study that concluded that "Managing Family Responsibilities, Work Stress, Work Schedule Flexibility, and Job Qualities" were key factors in influencing voluntary turnover).

22. See Stanislav D. Dobrev, Career Mobility and Job Flocking, 34 SOC. SCI. RES. 800, 810 (2005); Saporta \& Farjoun, supra note 20, at 264-65, 272-73.

23. See Mary Mallon \& Laurie Cohen, Time for a Change? Women's Accounts of the Move from Organizational Careers to Self-Employment, 12 BRIT. J. MGMT. 217, 223 (2001). Cf. Vicki L. Dryfhout \& Sarah Beth Estes, Explaining the Gender Gap in Professors' Intentions to Leave, 43 Soc. Focus 109, $122(2010)$.

24. Spurr \& Sueyoshi, supra note 1 , at $813,817$.

25. Brockman, supra note 1 , at 135 .

26. Nicola Patterson \& Sharon Mavin, Women Entrepreneurs: Jumping the Corporate Ship and Gaining New Wings, 27 INT'L. SMall BUS. J. 173, 175 (2009).

27. See Fiona M. Kay \& Elizabeth H. Gorman, Developmental Practices, Organizational Culture, and Minority Representation in Organizational Leadership: The Case of Partners in Large U.S. Law Firms, 639 AnNALS AM. ACAD. Pol. \& Soc. SCI. 91, 94 (2012). 
colleagues, play an important role in encouraging work engagement and access to challenging assignments. ${ }^{28} \mathrm{~A}$ positive relationship with colleagues may build organizational commitment, thereby lowering intentions to quit.

Again, women appear disadvantaged on this front, as they are overlooked by possible mentors and left off challenging cases. The literature on the legal profession documents women's lack of mentors and developmental experiences and reduced promotion prospects, particularly in law firms. ${ }^{29}$ Brockman's study also documents other job resources, such as access to clients and assignment of files, where women were disadvantaged, thereby reducing their subsequent opportunities for promotions. ${ }^{30}$ In a study based on in-depth interviews with one-hundred attorneys in the Denver metropolitan area, Nancy Reichman and Joyce Wallace Sterling argue that:

[W]omen's 'choices' reflect their ability to accumulate professional assets balanced against the pull of the family. Women described their disappointing experiences with work assignments, lack of recognition of their abilities, [and] problems they experienced while trying to find an influential mentor. The stories about work that we gathered suggest that choice may be as much about the push away from work as it is about the pull of the family. ${ }^{31}$

Furthermore, Jean Wallace's survey of Calgary lawyers shows that "intrinsic and professional job rewards and work demands significantly influence lawyers' dissatisfaction and desire to leave" the legal field. ${ }^{32}$ Wallace finds that when women lawyers' work is sufficiently

28. See Dail Fields et al., Exploring Predictors of Alternative Job Changes, 78 J. OcCupational \& ORGanizational Psychol. 63 (2005); Lucy Firth et al., How Can Managers Reduce Employee Intention to Quit?, 19 J. MANAGERIAL PSYCHOL. 170, 177, 179-180 (2004); Ellen F. Jackofsky \& Lawrence H. Peters, Job Turnover Versus Company Turnover: Reassessment of the March and Simon Participation Hypothesis, 68 J. APPLIED PSYCHOL. 490 (1983); Annet H. de Lange et al., Should I Stay or Should I Go? Examining Longitudinal Relations Among Job Resources and Work Engagement for Stayers Versus Movers, 22 WORK \& STRESS 201 (2008).

29. See Christine M. Beckman \& Damon J. Phillips, Interorganizational Determinants of Promotion: Client Leadership and the Attainment of Women Attorneys, 70 AM. Soc. REv. 678, 680, 696-97 (2005); Fiona M. Kay \& John Hagan, Raising the Bar: The Gender Stratification of Law-Firm Capital, 63 AM. Soc. REv. 728, 729-30 (1998); Reichman \& Sterling, supra note 1, at 941-61.

30. Brockman, supra note 1 , at 136.

31. Reichman \& Sterling, supra note $\mathbf{1}$, at $\mathbf{9 6 1 .}$

32. Wallace, supra note 1 , at 138 . 
challenging and service oriented, while not conflicting with their home life, they are more satisfied with and, in fact, are more committed to the practice of law than their male colleagues. ${ }^{33}$

Consistent with attitudinal theories of job satisfaction and turnover, we hypothesize that lawyers' satisfaction with content of work, opportunities for promotions ("power-track"), and collegiality will encourage retention in private practice.

Hypothesis 1a: High satisfaction with content of legal work is positively related to retention.

Hypothesis 1b: High satisfaction with opportunities for advancement, income, and prestige is positively related to retention.

Hypothesis 1c: High satisfaction with coworker relationships is positively related to retention.

We also expect that while men and women are similarly satisfied overall with their professional work, gender differences emerge with reference to specific forms of job satisfaction, including content of work, promotion opportunities, and collegiality. Such differences may contribute to gender disparities in departures from private law practice.

Hypothesis 1d: Men assess their job satisfaction with content of work, opportunities for advancement, and coworkers' support more positively than women assess these same job attributes.

\section{B. Family Pressures and the Firm}

Another argument commonly invoked in explaining job turnover describes women lawyers as opting out of their careers to raise their young children. This approach views women's voluntary exits from law firms as a strategic adaptation in the face of demanding responsibilities of work and home life. ${ }^{34}$ As a result of conflicting demands of work and family, women are seen as more apt to leave law firms and even jettison the profession entirely. ${ }^{35}$ In support of the opting out argument,

33. $I d$.

34. See e.g., Pamela Stone, Opting Out? Why Women Really Quit Careers and HeAd Home (2007); Phyllis Moen, It's Constraints, Not Choices, 319 ScIEnce 903 (2008); Phyllis Moen et al., Does Enhancing Work-Time Control and Flexibility Reduce Turnover? A Naturally Occurring Experiment, 58 Soc. ProBs. 69, 70, 72 (2011); Pamela Stone \& Meg Lovejoy, Fast-Track Women and the "Choice" to Stay Home, 596 ANNALS AM. ACAD. POL. \& Soc. ScI. 62, 63 (2004). See generally Lisa Belkin, The Opt-Out Revolution, N.Y. TiMES, Oct. 26, 2003, at 42 (analyzing why high-profile women were leaving their careers through personal interviews).

35. See Joan C. Williams et al., "Opt Out" or Pushed Out?: How the Press Covers WORK/FAMILY CONFLICT: THE UNTOLD STORY OF WHY WOMEN LEAVE THE WORKFORCE 4-6 (2006); Sylvia Ann Hewlett \& Carolyn Buck Luce, Off-Ramps and On-Ramps: Keeping Talented Women on the Road to Success, 83 HARV. BuS. REV. 43, 43 (2005); Arielle 
research has shown that the overall workload of managing career and family, as well as the negative spillover from work to home (e.g. requirements to work evenings and weekends) or from home to work (e.g. interruptions at work to deal with childcare issues), predict job turnover and turnover intentions. ${ }^{36}$ In addition, men and women professionals tend to cite different reasons for leaving jobs, with women being more likely than men to cite reasons such as childcare responsibilities, illness in the family, pregnancy, and the desire to have a job closer to home. ${ }^{37}$ As Kathleen Donovan phrased it, "[t]he most notorious reason for women to leave [a firm] is motherhood."38 Consistent with the opting out framework, we test the following hypothesis.

Hypothesis 2: The presence of children in the home is positively related to women's exits from private law practice.

However, recent work challenges the assumed trend of opting out among women professionals. In a landmark study, Christine Percheski conducted a rigorous analysis to assess "whether recent cohorts of women in professional and managerial occupations are increasing or maintaining high employment rates or if they are opting out of employment to stay home with [their] children." ${ }^{39}$ Percheski used data from the 1960 through 2000 American Censuses and the American Community Survey for $2004 .{ }^{40} \mathrm{Her}$ analysis suggests that, in fact, there has been an increase of full-time year-round employment among younger cohorts of women, even among mothers of young children.41 Further, women working in historically male-dominated occupations (including law) have the highest full-time employment rates. Other studies support Percheski's claims, showing no trend toward opting out among highly-educated women. For example, Claudia Goldin found that

Kuperberg \& Pamela Stone, The Media Depiction of Women Who Opt Out, 22 Gender \& Soc. 497, 497-98 (2008); Belkin, supra note 34 .

36. See Armstrong et al., supra note 21, at 149 (finding that work and family pressure influences job turnover for women IT professionals); Eli Jones et al., The Role of Overload on Job Attitudes, Turnover Intentions, and Salesperson Performance, 60 J. BUS. RES. 663, 665,668 (2007) (concluding that role overload for salespeople positively impacts turnover intentions); Phyllis Moen \& Qinlei Huang, Customizing Careers by Opting Out or Shifting Jobs: Dual-Earners Seeking Life-Course "Fit", in WoRKPlaCe FleXIBILITY: REALIGNING 20TH-CENTURY JOBS FOR A 21ST-CENTURY WORKFoRCE 73, 82 (Kathleen Christensen \& Barbara Schneider eds., 2010).

37. Nachum Sicherman, Gender Differences in Departures from a Large Firm, 49 INDUS. \& LAB. REL. REV. 484, 488 (1996).

38. Kathleen Donovan, Women Associates' Advancement to Partner Status in Private Law Firms, 4 GEO. J. LEGAL ETHICS 135, 142 (1990).

39. Percheski, supra note 12 , at 497.

40. Id. at 502 .

41. Percheski, supra note 12 , at 513. 
women with professional or graduate degrees have high rates of employment, return to work following short interruptions for children, and have low rates of opting out. ${ }^{2}$ Similarly, Wallace found that, compared with men, "women [lawyers] are . . . less likely to want to leave the practice of law[,]" and neither marital status nor presence of preschool-aged children affects lawyers' job dissatisfaction or desire to leave the practice of law. ${ }^{43}$

The central flaw of the opting out argument is that it pays little attention to structural aspects of the workplace. Instead, the framework blames women professionals, implying that working mothers fail to manage their multiple roles effectively and make the choice to leave their careers to stay home with their children. The language of opting out overlooks other factors, such as inflexible workplaces, labor market instability, men's lower contributions to housework, unstable childcare arrangements, and other reasons why women may not work outside the home. ${ }^{44}$ We consider these broader issues next.

\section{Organizational Context and Available Options}

Numerous studies suggest that women's exits from private practice are in fact the result of a broader range of reasons than childbearing and a decision to stay home with children. In a study of Alberta lawyers, Brockman found that women often report leaving the legal field due to the lack of flexibility offered by law firms, excessively long hours, childcare commitments, and stressful nature of work.45 And while part-time schedules may be offered in employers' formal policies, most lawyers refrain from part-time schedules for fear of damaging their career. ${ }^{46}$ These studies hint at the fact that what others have called opting out more accurately consists of women making career adaptations (e.g. reduced hours, shifting areas of practice, and slower promotion tracks), or even temporary or long-term exits from their careers, as a consequence of being pushed out by the rigid inflexibilities of their work environment. ${ }^{47}$

42. Claudia Goldin, The Quiet Revolution That Transformed Women's Employment, Education, and Family, 96 AM. ECON. REV. 1, 17 (2006).

43. Wallace, supra note 1 , at 136 .

44. See Heather Boushey, "Opting Out?" The Effect of Children on Women's Employment in the United States, 14 FEMINIST ECON. 1, 31 (2008).

45. Brockman, supra note 1 , at 129-30.

46. Rhode, supra note 10 , at 1008. See generally HILARY SOMMERLAD \& PETER SANDERSON, GENDER, CHOICE AND COMMITMENT: WOMEN SOLICITORS IN ENGLAND AND WALES AND THE STRUGGLE FOR EQUAL STATUS (1998).

47. Moen et al., supra note 34, at 78; Stone \& Lovejoy, supra note 34 , at 80. 
From this perspective, individuals' choices are bound by organizational structures and cultures. ${ }^{48}$ In the context of law, lawyers often work in firms that define the options in terms of career ladders, full-time and part-time work options, and leaves and benefit plans. ${ }^{49}$ Firms also convey expectations about caseload, hours, and delivery of legal services.50 However, it is not only workplace benefits and organizational structures that constrain (or enable) lawyers' choices. Practices within the firm, such as a culture that places a strong emphasis on billings, establish further strictures. The emphasis on billable hours conveys to junior lawyers a firm's "engrained cultural beliefs and practices around work time and face time as indicators of work commitment, productivity, and quality." 51 The emphasis on organizational context and available options shifts research away from the opting out rhetoric of individual choice. Rather, the focus is directed to rising pressures with increasing billable hour quotas ${ }^{52}$ and "time cages" of professional work ${ }^{53}$ as pivotal to job turnover. ${ }^{54}$

One way in which professionals may adapt to increased family commitments is through work schedule flexibility. Organizational provisions such as schedule flexibility may moderate the effects of increasing family responsibilities on job turnover by providing lawyers with greater ability to manage what are often competing demands. ${ }^{55}$ To the extent that turnover intentions reflect the absence of work-life balance, planning to leave a job with extreme demands can be a strategy to achieve a better sense of fit. ${ }^{56}$ Work schedule flexibility may offer the needed bridge between the work and family roles by enabling legal

48. See e.g., Stewart R. Clegg, Frameworks of Power (1989); Moen et al., supra note 34 (enhancing work-time control and flexibility would reduce turnover in the workplace); Mary Jane Mossman, Lawyers and Family Life: New Directions for the 1990's, 2 FEMINIST LEGAL STUD. 159 (1994) (cataloguing varying work arrangements); Charles D. Weisselberg \& Su Li, Big Law's Sixth Amendment: The Rise of Corporate White-Collar Practices in Large U.S. Law Firms, 53 ARIz. L. REv. 1221, 1224 (2011) (finding that the culture and economic practice of firms have encouraged lateral movements of both government and private counsel to white-collar practice).

49. Brockman, supra note 1 , at 52-67.

50. Lieper, supra note 6, at 79-104.

51. Moen et al., supra note 34 , at 72 .

52. See, e.g., Cynthia Fuchs Epstein, Border Crossings: The Constraints of Time Norms in Transgressions of Gender and Professional Roles, in Fighting FoR TIME: SHIfTiNG BOUNDARIES OF WORK AND SoCIAL LIFE 317 (Cynthia Fuchs Epstein \& Arne L. Kalleberg eds., 2004); Rhode, supra note 10, at 1008.

53. Moen et al., supra note 34 , at 71 .

54. See Brockman, supra note 1 , at 129.

55. See Moen et al., supra note 34 , at 70 .

56. See generally STONE, supra note 34, at 80-104 (discussing various instances of women leaving demanding employment for better family balance). 
professionals to take advantage of shorter or pliable work schedules and to take time off for personal matters. Research demonstrates that flexible work schedules are associated with higher organizational commitment, greater job satisfaction, ${ }^{57}$ lower stress and lower work-family conflict, ${ }^{58}$ and reduced job leaving. ${ }^{59}$ Further, organizations that offer flexible scheduling and family-friendly policies may enhance lawyers' commitment to the firm by building a work environment where the firm leaders are viewed as being fair, accommodating, and valuing the skills offered by lawyers employed in the firm. ${ }^{60}$

Hypothesis 3: The availability of flexible work schedules will decrease the rate of exits from private practice.

\section{Globalization, Economic Instability, and Changing Firm Structures}

It is important to acknowledge that the organizational contexts in which many private practice lawyers work, law firms, have changed dramatically in recent years. The global expansion of law firms has seen the growth of foreign offices with an emphasis on corporate mergers and acquisitions work. ${ }^{61}$ Law firms have expanded dramatically in size over the last three decades, and this growth is accompanied with an increase in the number of branch offices, domestically and internationally. ${ }^{62}$ Increased leverage (rising numbers of associates relative to the number of partners) has developed with the growth in size and geographic scope of large law firms. ${ }^{63}$ And the tournament model, ${ }^{64}$ which claimed firms operate as an up-or-out pyramid structure, has changed to incorporate

57. Terri A. Scandura \& Melenie J. Lankau, Relationships of Gender, Family Responsibility and Flexible Work Hours to Organizational Commitment and Job Satisfaction, 18 J. ORGANIZATIONAL BEHAV. 377, 377 (1997).

58. Armstrong et al., supra note 21 , at 149 .

59. See, e.g., Fredrik Heyman, How Wage Compression Affects Job Turnover, 29 J. LAB. RES. 11, 19 (2008).

60. See Craig D. Crossley et al., Development of a Global Measure of Job Embeddedness and Integration into a Traditional Model of Voluntary Turnover, 92 J. APPLIED PSYCHOL. 1031,1041 (2007).

61. See, e.g., D. Daniel Sokol, Globalization of Law Firms: A Survey of the Literature and a Research Agenda for Further Study, 14 IND. J. GLoBAL LEGAL STUD. 5, 10-11 (2007) (finding a high concentration of international firms in mergers and acquisitions work compared with local firms).

62. See William D. Henderson, An Empirical Study of Single-Tier versus Two-Tier Partnerships in the Am. Law 200, 84 N.C. L. REV. 1691, 1694-95; Sokol, supra note 61, at 7.

63. See generally Sokol, supra note 61.

64. See James R. Faulconbridge, Relational Networks of Knowledge Production in Transnational Law Firms, 38 GEOFoRUM 925 (2007) (examining the production and circulation of knowledge in transnational legal firms). 
at least two stages to the tournament in most large law firms. ${ }^{65}$ The first stage of the tournament is the promotion from the ranks of associate to partner. The second stage occurs at the partner level in which nonequity (service or salaried) partners battle to join the ranks of equity (owners, profit-sharing) partners. The two-tier model has become the norm in many of the large law firms, particularly those with multiple offices. ${ }^{66}$ Globalization of firms also raises new challenges for strategic decision-making and competitive expansion, 67 networks of knowledge transfer and cohesive firm cultures, 68 and professional autonomy in a managerial model of firm expansion. ${ }^{69}$

Beyond globalization and changing firm hierarchies, private practice more generally has seen significant changes in recent years. There has been a decline in the traditional model of solo practice and small partnerships, ${ }^{70}$ causing a shift to larger firms. ${ }^{71}$ Demographics have also changed with rising numbers of women and racial minorities entering law. ${ }^{72}$ Lawyers working in law firms and solo practice encounter increasing infringement on their territories of practice (by accountants, realtors, notaries, and paralegals), eroding lawyers' monopoly over services. ${ }^{73}$

65. See James Faulconbridge \& Daniel Muzio, Organizational Professionalism in Globalizing Law Firms, 22 WORK, EMP. \& SOC'Y 7, 10 (2008).

66. See Henderson, supra note 62, at 1694-95; Sokol, supra note 61, at 7.

67. See generally Sokol, supra note 61.

68. See Faulconbridge, supra note 64 (examining the production and circulation of knowledge in transnational legal firms).

69. See Faulconbridge \& Muzio, supra note 65, at 10 (explaining the impact of managerialization and commercialization on professional autonomy).

70. See Elizabeth H. Gorman \& Rebecca L. Sandefur, "Golden Age," Quiescence, and Revival: How the Sociology of Professions Became the Study of Knowledge-Based Work, 38 WORK \& OCCUPATIONS 275, 280 (2011).

71. Cf. Kevin T. Leicht \& Mary L. Fennell, The Changing Organizational Context of Professional Work, 23 ANN. REV. Soc. 215, 217 (1997).

72. See, e.g., DINOVITZER ET AL., supra note 19, at 19; CYNTHIA FUCHS EPSTEIN, WOMEN IN LAW (2d ed. 1993); Elizabeth H. Gorman \& Fiona M. Kay, Racial and Ethnic Minority Representation in Large U.S. Law Firms, 52 STUD. L., POL., \& Soc'Y 211, 212 (2010); Kay \& Gorman, supra note 27 (arguing that developmental practices of large law firms do not level the playing field for minorities); Fiona Kay \& Elizabeth Gorman, Women in the Legal Profession, 4 ANN. REV. L. \& SoC. SCI. 299 (2008).

73. See Fiona M. Kay, Professional Monopolies and Divisive Practices in Law: Les Femmes Juridiques' in Civil Law, Canada, 4 INT'L J. L. CoNTEXT. 187, 191-93 (2008) (exploring the relationship between civil law notaires and public law avocats); Chang Hwan Kim \& Arthur Sakamoto, Does Inequality Increase Productivity? Evidence from U.S. Manufacturing Industries, 1979 to 1996, 35 WORK \& OCCUPATIONS 85 (2008) (arguing that the increase in computerized services has caused a downsizing of middle-level, white-collar jobs); Stefan Timmermans, Professions and Their Work: Do Market Shelters Protect Professional Interests?, 35 WORK \& OCCUPATIONS 164 (2008) (arguing that effective 
The nature of legal work is also changing across various practice settings. In recent years, there has been a ratcheting up of workloads and time pressures on legal professionals. ${ }^{74}$ Some scholars argue that the "boundedness" of working time is evaporating with the use of information technologies and that the mounting expectations that lawyers be available to their clients and law firms at any hour, including weeknights and weekends, further contribute to stress. ${ }^{75}$ The expansion of hours demanded in legal practice contributes to work balance issues, particularly for women who typically bear a heavier share of childcare responsibility. ${ }^{76}$

The escalating time pressures combined with a lack of workplace policies to accommodate family responsibilities may prompt some women to interrupt their careers in private practice, making moves to more predictable hours in government work or leaving the labor market entirely for a period of time. Certainly, the dominant model of career progression 77 has assumed an "ideal worker,"78 one whose career is both linear and continuous. ${ }^{79}$ In contrast, women have more often tended to experience interrupted, nonlinear careers due largely to family commitments. ${ }^{80}$ Perhaps women's careers are not the only anomalous ones in today's economy. The careers of both men and women lawyers may be subject to greater flux, including discontinuous career paths, as a result of globalization, economic recessions, rise in dual-professional

market shelters protect professions from outside pressures but also may thwart innovation).

74. Cf. Jerry A. Jacobs \& Kathleen Gerson, The Time Divide: Work, Family and Gender Inequality 2 (2004); Phyllis Moen \& Yan Yu, Effective Work/Life Strategies: Working Couples, Work Conditions, Gender, and Life Quality, 47 Soc. Probs. 291, 292 (2000).

75. Moen et al., supra note 34 , at 89. See Carroll Seron \& Kerry Ferris, Negotiating Professionalism: The Gendered Social Capital of Flexible Time, 22 WORK \& OccuPATIONS 22,23 (1995).

76. See, e.g., Kenneth G. Dau-Schmidt et al., Men and Women of the Bar: The Impact of Gender on Legal Careers, 16 MiCH. J. GENDER \& L. 49, 67 (2009).

77. See generally Hanna Papanek, Men, Women, and Work: Reflections on the Two-Person Career, 78 AM. J. Soc. 852 (1973) (arguing that women's career interests are derailed due to the societally-constructed role of women as subsidiary to their husband's careers).

78. See JOAN WILllams, UNBENDING GENDER: WHy FAMILY AND WORK CONFLICT AND WHAT TO DO ABOUT IT 1 (2000).

79. See Carmen Sirianni \& Cynthia Negrey, Working Time as Gendered Time, 6 FEMINIST ECON. 59, 66 (2000).

80. See Nanette Fondas, Feminization at Work: Career Implications, in THE BOUNDARYLESS CAREER: A NEW EMPLOYMENT PRINCIPLE FOR A NEW ORGANIZATIONAL ERA 282, 285 (Michael B. Arthur \& Denise M. Rousseau eds., 1996); Mallon \& Cohen, supra note 23 , at 226 . 
couples, and changes in job conditions in modern firms. ${ }^{81}$ We know little about the impact of interruptions, such as their length and nature, on the careers of legal professionals.

We surmise that interruptions that are long in duration, the result of a single extended leave or a series of short leaves, will augment the chances of leaving private practice. Law firm leaders may view these interruptions as a lack of commitment by the lawyer, and interruptions longer in duration may also indicate a lawyer's serious engagement with other possible ventures (e.g. establishing a business or entering politics). The nature of the interruption may matter as well. Parental leaves, in particular, may not receive the same acceptance as those leaves taken by lawyers for the purposes of working as in-house counsel, campaigning for election in politics, or serving in the government. Each of these pursuits may be viewed as bringing rich assets to the firm, including the development of new expertise or the channeling of new, lucrative clients to the firm. We therefore suggest two hypotheses related to interruptions from law practice.

Hypothesis 4a: Gaps between jobs, especially for long durations, will hasten departures from private practice.

Hypothesis 4b: Taking a parental leave will increase the risk of leaving private practice.

The broader economic context is also salient to the career progression of lawyers in private practice. A sizeable body of literature suggests economic climate influences turnover. ${ }^{82}$ Periods of both economic decline and prosperity may prompt an increase in job movement, albeit for different reasons. Poor economic conditions at the time of career launch may lead law graduates to change jobs in an effort to land a desirable or secure position. They may also quit their jobs as preemptive moves to avoid the impact of downsizes, partnership denials, and partnership dissolutions, ${ }^{83}$ or they may be terminated prematurely and become casualties of difficult economic times. In contrast, when the economy is prosperous, there may be a high tendency for people to hop among different organizations for career advancement. ${ }^{84}$ We suspect

81. See Moen et al., supra note 34 .

82. See generally Kenneth A. Couch \& Robert Fairlie, Last Hired, First Fired? Black-White Unemployment and the Business Cycle, 47 DEMOGRAPHY 227 (2010); Heyman, supra note 59; Hyunjoon Park \& Gary D. Sandefur, Racial/Ethnic Differences in Voluntary and Involuntary Job Mobility Among Young Men, 32 Soc. SCI. RES. 347 (2003); Steel, supra note 13 (discussing the effect of perceived job market alternatives on turnover).

83. See Couch \& Fairlie, supra note 82, at 240 (finding no relationship between the business cycle and transitioning from employment to nonparticipation).

84. See Vincent Cho \& $\mathrm{Xu}$ Huang, Professional Commitment, Organizational Commitment, and the Intention to Leave for Professional Achievement, 25 INFO. TECH. \& 
that the latter mobility pattern occurs primarily in the form of firm-to-firm job changes, a jockeying for preferred positioning in the private practice marketplace, rather than movement across sectors of law practice. Meanwhile, a difficult economic climate, especially one that clouds the labor market as new graduates enter private practice, is likely to cause significant instability, prompting lawyers to seek jobs across sectors of practice or to exit law practice entirely. We pose one final hypothesis, which is centered on economic climate at time of career entry.

Hypothesis 5: A high unemployment rate at time of entry to career is a significant and positive predictor of leaving private practice.

\section{E. Data, Measures, and Methods}

The source of data for this study comes from a longitudinal panel survey of lawyers in the province of Ontario. In the Canadian context, Ontario is an ideal setting to study legal careers because the province is home to nearly half (41 percent) of the nation's lawyers. ${ }^{85}$ We collected data at four time points and at six- to eight-year intervals: 1990, 1996, 2002 , and 2009. The relatively short intervals were chosen in an effort to capture knowledge of recent job histories and workplace conditions while these events and situations were still fresh in participants' minds. The original sample consisted of a disproportionately stratified, random sample of lawyers from the membership records of the Law Society of Upper Canada. The sample was stratified by gender to include equal numbers of men and women admitted to the Ontario Bar between 1975 and 1990, a period in which the first sizeable number of women entered law practice. The questionnaires were mailed directly to respondents' places of employment. The 1990 survey, with one reminder, received a 68 percent response rate $(\mathrm{N}=1,597)$. In 1996 , we conducted a second survey of this same sample. Through a single reminder, we obtained a response rate of 70 percent. The third wave of survey data collection, which took place in 2002 with two reminders, received a response rate of 73 percent. The fourth and final survey took place in 2009, again with two reminders, and received a response rate of 68 percent. The four

PEOPle 31, 32 (2012); Anneleen Forrier et al., Career Mobility at the Intersection Between Agent and Structure: A Conceptual Model, $82 \mathrm{~J}$. OCCUPATIONAL \& ORGANIZATIONAL PSYCHOL. 739, 745 (2009).

85. See Fiona M. Kay \& Joan Brockman, Barriers to Gender Equality in the Canadian Legal Establishment, 8 FEMINIST LEGAL STUD. 169, 174 (2000); Fiona M Kay \& John Hagan, Social Mobility and Hierarchical Structure in Canadian Law Practice, in REORganisation and Resistance: Legal Professions Confront a Changing WorLd 281, 284 (William LF Felstiner ed., 2005). 
surveys yielded very respectable response rates (close to 70 percent each mailing).

The surveys were designed using a unique format, including a professional work history calendar summarizing job changes across time. These rich data were collected at six-year intervals with each survey mailing gathering information on up to eight professional positions. Each survey also included a range of other questions about job satisfaction, workplace responsibilities, and organizational context, as well as questions about life outside law, including marriages, children, and parental leaves. The four waves of surveys, conducted in 1990, 1996,2002 , and 2009, were then merged together, and the work and life histories were nested into each individual's record or biography. Conducting survey waves every six years minimized inconsistent autobiographical reconstructions and recall difficulties. ${ }^{86}$

Our analysis includes several independent variables to test the hypotheses outlined above. Among our demographic and family variables, we included gender $(1=$ female), racial minority ( $1=$ minority), and marital status ( $1=$ married or cohabiting). We measured children in terms of four dummy variables: one, two, three, and four or more children (with no children as the comparison category).

We tapped human capital through five variables. Elite law school was defined as the University of Toronto, the highest ranked university and the highest tuition in the province (1=University of Toronto) ${ }^{87}$ Areas of law were coded as business law (including corporate commercial, banking, securities, industrial and intellectual property, and tax), litigation, people law (including social welfare, other administrative law, wills and estates, family, labor, and real estate), and criminal law, following the work of Elizabeth Gorman. ${ }^{88}$ The hours worked variable required lawyers to report the number of hours they worked each week, including day, evening, and weekend hours. Client recruitment tapped whether lawyers had primary responsibility for clients of the firm (coded 0 ) or clients they brought in (coded 1). We also assessed the amount of time lawyers devoted to corporate clientele, with

86. See Anna Manzoni et al., Memory Bias in Retrospectively Collected Employment Careers: A Model-Based Approach to Correct for Measurement Error, 40 Soc. METHODOLOGY 39, 43-44 (2010).

87. MacLean's magazine ranks the University of Toronto first among Canadian common law schools based on elite firm hiring, national reach, Supreme Court clerkships, faculty hiring, and faculty journal citations. See The 2012 Maclean's Law School Rankings, MACLEANS.CA ON CAMPUS (Sept. 7, 2012 12:17 PM), http://oncampus.macleans .ca/education/2012/09/07/the-2012-macleans-law-school-rankings.

88. See Elizabeth H. Gorman, Work Uncertainty and the Promotion of Professional Women: The Case of Law Firm Partnership, 85 SOC. FORCES 865, 874 (2006). 
more than 50 percent of their time spent representing corporate clients (coded 1).

Next, we captured the initial organizational setting in terms of organizational size, desirability of first job, geographic location, and economic climate at time of entry to law. We asked lawyers to describe their first job in private practice as either solo practice or law firm. We then coded the size of firms in terms of small firms of less than ten lawyers, small mid-sized firms of ten to nineteen lawyers, large mid-sized firms of twenty to forty-nine lawyers, and large firms of fifty or more lawyers. We entered solo practice and the various firm size variables as a series of dummy variables in the regression models.

We asked lawyers how their current position compared with the one they originally wanted after bar admission. This variable, landed first job desired, was coded: $1=$ nothing like; $2=$ little of what; $3=$ some of what; $4=$ mostly what; and $5=$ exactly what they wanted. Lawyers reported whether they started their careers in the Greater Toronto Area $(\mathrm{GTA}=1)$ or elsewhere. We also included in our analysis a measure of unemployment rate at the time each yearly cohort was admitted to the Ontario Bar (range=6.9 to 11.8).

In addition, we included a set of variables intended to assess job satisfaction and workplace benefits. We measured job satisfaction in terms of three dimensions. Satisfaction with content of work asked lawyers to rate their level of satisfaction with the nature of the work. We also asked lawyers to assess their level of satisfaction with working relationships with colleagues as a measure of collegiality. Another composite measure tapped lawyers' satisfaction with the "power-track" in their work setting. This scale asked lawyers to rank their level of satisfaction with income, prestige of work, and opportunity for advancement (alpha=.78). ${ }^{89}$ Prior research demonstrates the importance of separating out dimensions of job satisfaction rather than using a global measure of job satisfaction. 90 This differentiation is important because studies have shown women and men share similar levels of general satisfaction, while at the same time there are gender differences

89. "Each of the [job] satisfaction items is a descriptive statement about the [professional position] to which the respondent is asked to respond. The use of descriptive statements to draw inferences about facet-specific job satisfaction is consistent with the methods used in [many] of the most popular job satisfaction instruments . . . today." Richard Lichtenstein et al., Status Differences in Cross-Functional Teams: Effects on Individual Member Participation, Job Satisfaction, and Intent to Quit, 45 J. HEALTH \& SOC. BEHAV. 322, 327-28 (2004). "Each item was scaled on a seven-point [strongly] disagree [to strongly] agree continuum, and the resulting measure represents the mean score of the respective items." Id. at 328.

90. See, e.g., Ronit Dinovitzer \& Bryant G. Garth, Lawyer Satisfaction in the Process of Structuring Legal Careers, 41 LAW \& SOC'Y REV. 1, 2 (2007). 
on specific facets, such as promotions and substance of legal work. ${ }^{91}$ In addition, we inquired about work benefits, specifically, the flexibility of hours afforded at the early career stage. In the first wave of the survey (1990), we asked lawyers whether their job offered flexible work hours (on a full time basis) (coded $0=$ none; 1=yes). Sex discrimination measures whether the lawyer reported experiencing sexual discrimination "occasionally," "frequently," or "always present" (coded 1). Studies of promotion and retention often do not include measures of sexual discrimination; $; 2$ however, research suggests these perceived experiences are significant obstacles to women's successful integration in the profession. ${ }^{93}$

Finally, we included three measures designed to tap aspects of career breaks. The first measure, duration of interruptions, calculates the number of months between positions totaled across the lawyer's career to date (range $=0$ to 78). Parental leave measures whether the lawyer reported taking a parental leave during the course of their career, and other leaves measures whether they took a leave for purposes other than parental leave. Table 1 lists the operationalization and descriptive statistics of the variables used in this analysis.

91. E.g., Dinovitzer et al., supra note 19, at 58; John Hagan \& Fiona Kay, Even Lawyers Get the Blues: Gender, Depression, and Job Satisfaction in Legal Practice, 41 LAW \& Soc'Y REV. 51, 52-53 (2007) ("[W]omen as well as men lawyers . . report] that that they are highly satisfied with the substance of their work. ... There is evidence of specific issues such as job setting and advancement where women lawyers indicate somewhat less satisfaction than men lawyers.").

92. See, e.g., Noonan \& Corcoran, supra note 1, at 147.

93. See, e.g., MARGaRet THORNTON, DissonanCE AND DistruST: WOMEN IN THE LEGAL PROFESSION 216-67 (1996) (discussing "body politics"); GITA Z. WILDER, WOMEN IN THE PROFESSION: FindingS FROM THE First WAVE OF THE AFTER THE JD STUdY 25 (2007) (finding that women perceived discrimination and attributed such discrimination to negative work consequences in a greater proportion than men); Epstein, supra note 52, at 317 (analyzing "how time ideologies integrate with gender and work ideologies to undermine the ability of individuals to ... transgress the role boundaries that define the structure of their lives and their activities"); Rosemary Hunter, Talking Up Equality: Women Barristers and the Denial of Discrimination, 10 FEMINIST LEGAL STUD. 113 (2002) (discussing the effects of women in the legal profession denying sexual discrimination); Heleen F.P. Ietswaart, Choices in Context: Life Histories of Women Lawyers in the Netherlands, in WOMEN IN THE WORLD'S LEGAL PROFESSIONS 353 (Ulrike Schultz \& Gisela Shaw eds., 2003); Hilary Sommerlad, "Becoming" a Lawyer: Gender and the Processes of Professional Identity Formation, in CaLdING For CHANGE: WoMEN, LAW, AND THE LEGAL PROFESSION 159, supra note 10, at 160 (examining "[t]he social embeddedness of the profession"). 
Table 1. Operationalization and Measurement of Study Variables

\begin{tabular}{|c|c|c|c|c|c|c|}
\hline \multirow[b]{2}{*}{$\begin{array}{l}\text { Independent } \\
\text { Variables } \\
\end{array}$} & \multirow[b]{2}{*}{ Description } & \multicolumn{2}{|c|}{$\begin{array}{l}\text { Females } \\
(\mathrm{N}=576)\end{array}$} & \multirow[b]{2}{*}{$\chi^{2}$} & \multicolumn{2}{|c|}{ Males $(\mathrm{N}=558)$} \\
\hline & & $\begin{array}{c}\text { Mean } \\
(\%)\end{array}$ & SD & & $\begin{array}{c}\text { Mean } \\
(\%)\end{array}$ & SD \\
\hline \multicolumn{7}{|l|}{$\begin{array}{l}\text { Demographics } \\
\text { \& Family }\end{array}$} \\
\hline Racial minority & $\begin{array}{l}0=\text { nonracial minority; } \\
1=\text { racial minority. }\end{array}$ & .07 & .26 & * & .04 & .20 \\
\hline Married & $\begin{array}{l}0=\text { not married or } \\
\text { cohabiting; } 1=\text { married or } \\
\text { cohabiting }\end{array}$ & .81 & .39 & *** & .89 & .31 \\
\hline $\begin{array}{l}\text { Children: } \\
\text { none }\end{array}$ & \multicolumn{5}{|c|}{ Children: } & .42 \\
\hline 1 child & $0=$ else; $1=$ one child. & .15 & .36 & & .14 & .35 \\
\hline 2 children & $0=$ else $; 1=$ two children. & .30 & .46 & $\star \star$ & .36 & .48 \\
\hline 3 children & $0=$ else $1=$ three children. & .17 & .38 & & .19 & .40 \\
\hline 4+ children & $\begin{array}{l}0=\text { else; } 1=\text { four or more } \\
\text { children. }\end{array}$ & .07 & .26 & & .07 & .26 \\
\hline $\begin{array}{l}\text { Wave 1: First } \\
\text { Job: } \\
\text { Human Capital }\end{array}$ & & & & & & \\
\hline $\begin{array}{l}\text { Elite law school } \\
\text { Areas of law }\end{array}$ & $\begin{array}{l}0=\text { other law schools; } \\
1=\text { University of Toronto }\end{array}$ & .13 & .34 & & .14 & .35 \\
\hline Business law & $\begin{array}{l}0=\text { else } 1=\text { corporate } \\
\text { commercial, banking, } \\
\text { securities, industrial and } \\
\text { intellectual property, and } \\
\text { tax. }\end{array}$ & .20 & .40 & & .19 & .39 \\
\hline Litigation & $0=$ else; $1=$ civil litigation. & .23 & .42 & & .27 & .44 \\
\hline People law & $\begin{array}{l}0=\text { else; } 1=\text { social welfare, } \\
\text { other administrative law, } \\
\text { wills and estates, family, } \\
\text { labor, real estate. }\end{array}$ & .47 & .50 & & .43 & .50 \\
\hline Criminal law & $0=$ else $1=$ criminal law. & .04 & .20 & * & .07 & .26 \\
\hline Hours per week & $\begin{array}{l}\text { Hours worked per week, } \\
\text { including day, evening and } \\
\text { weekends. }\end{array}$ & 38.81 & 11.23 & + & 40.18 & 13.65 \\
\hline $\begin{array}{l}\text { Client } \\
\text { recruitment }\end{array}$ & $\begin{array}{l}\text { Primary responsibility for } \\
\text { clients of the firm }(=0) \\
\text { versus clients the lawyer } \\
\text { brings in }(=1)\end{array}$ & .22 & .42 & *** & .35 & .48 \\
\hline $\begin{array}{l}\text { Corporate } \\
\text { clients }\end{array}$ & $\begin{aligned} 0= & \text { proportion of time spent } \\
& \text { representing corporate } \\
& \text { clients less than } 50 \% ; \\
& 1=\text { more than } 50 \% \text { of time }\end{aligned}$ & .30 & .46 & * & .35 & .48 \\
\hline $\begin{array}{l}\text { Organizational } \\
\text { Setting }\end{array}$ & $\begin{array}{l}\text { spent representing } \\
\text { corporate clients. }\end{array}$ & & & & & \\
\hline Solo practice & $0=$ firm; $1=$ solo practitioner. & .08 & .27 & & .10 & .30 \\
\hline Small firm & $0=$ else; $1=$ less than 10 & .49 & .02 & & .53 & .50 \\
\hline
\end{tabular}




\begin{tabular}{|c|c|c|c|c|c|c|}
\hline & lawyers. & & & & & \\
\hline $\begin{array}{l}\text { Small mid-size } \\
\text { firm }\end{array}$ & $0=$ else; $1=10.19$ lawyers. & .11 & .31 & & .11 & .31 \\
\hline $\begin{array}{l}\text { Large } \\
\text { mid-sized firm }\end{array}$ & $0=$ else; $1=20-49$ lawyers. & .10 & .30 & & .09 & .28 \\
\hline Large firm & $\begin{array}{l}0=\text { else; } 1=50 \text { or more } \\
\text { lawyers. }\end{array}$ & .23 & .42 & * & .18 & .38 \\
\hline $\begin{array}{l}\text { Landed first } \\
\text { job desired }\end{array}$ & $\begin{array}{l}\text { How this position compared } \\
\text { with the one the } \\
\text { respondent originally } \\
\text { wanted after bar } \\
\text { admission: } 1=\text { nothing } \\
\text { like; } 2=\text { little of what; } \\
3=\text { some of what; } \\
4=\text { mostly what; and } \\
5=\text { exactly what they } \\
\text { wanted. }\end{array}$ & 3.72 & 1.14 & & 3.78 & 1.17 \\
\hline $\begin{array}{l}\text { Greater } \\
\text { Toronto Area }\end{array}$ & $\begin{array}{l}0=\text { elsewhere; } 1=\text { Greater } \\
\text { Toronto Area (GTA). }\end{array}$ & .57 & .50 & & .53 & .50 \\
\hline $\begin{array}{l}\text { Unemployment } \\
\text { rate at call }\end{array}$ & Range $=6.9-11.8$ & 8.84 & 1.55 & & 8.76 & 1.62 \\
\hline \multicolumn{7}{|l|}{$\begin{array}{l}\text { Job } \\
\text { Satisfaction }\end{array}$} \\
\hline $\begin{array}{l}\text { Content of } \\
\text { work }\end{array}$ & $\begin{array}{l}\text { Level of satisfaction with } \\
\text { nature of work, coded } \\
\text { from } 1=\text { very dissatisfied } \\
\text { to } 7=\text { very satisfied. }\end{array}$ & 5.70 & 1.08 & & 5.63 & 1.15 \\
\hline Power-track & $\begin{array}{l}\text { Level of satisfaction with } \\
\text { income, prestige of work, } \\
\text { and opportunity for } \\
\text { advancement, coded from } \\
1=\text { very dissatisfied to } \\
7=\text { very satisfied. Alpha } \\
\text { reliability }=.78 \text {. Scale } \\
\text { standardized in } \\
\text { regression. }\end{array}$ & 5.07 & 1.06 & & 5.13 & 1.13 \\
\hline Collegiality & $\begin{array}{l}\text { Level of satisfaction with } \\
\text { working relationship } \\
\text { with colleagues, coded } \\
\text { from } 1=\text { very dissatisfied } \\
\text { to } 7=\text { very satisfied. }\end{array}$ & 5.78 & 1.14 & & 5.61 & 1.19 \\
\hline $\begin{array}{l}\text { Flexible } \\
\text { schedule }\end{array}$ & $\begin{array}{l}0=\text { no; } 1=\text { flexible schedule } \\
\text { available on full-time } \\
\text { hours. }\end{array}$ & .30 & .46 & ** & .32 & .47 \\
\hline $\begin{array}{l}\text { Sexual } \\
\text { Discrimination }\end{array}$ & $\begin{array}{l}0=\text { has not experienced } \\
\text { sexual harassment or is } \\
\text { uncertain; } 1=\text { has } \\
\text { personally experienced } \\
\text { sexual discrimination } \\
\text { occasionally, frequently, or } \\
\text { always present. }\end{array}$ & .74 & .44 & 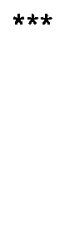 & .11 & .32 \\
\hline
\end{tabular}




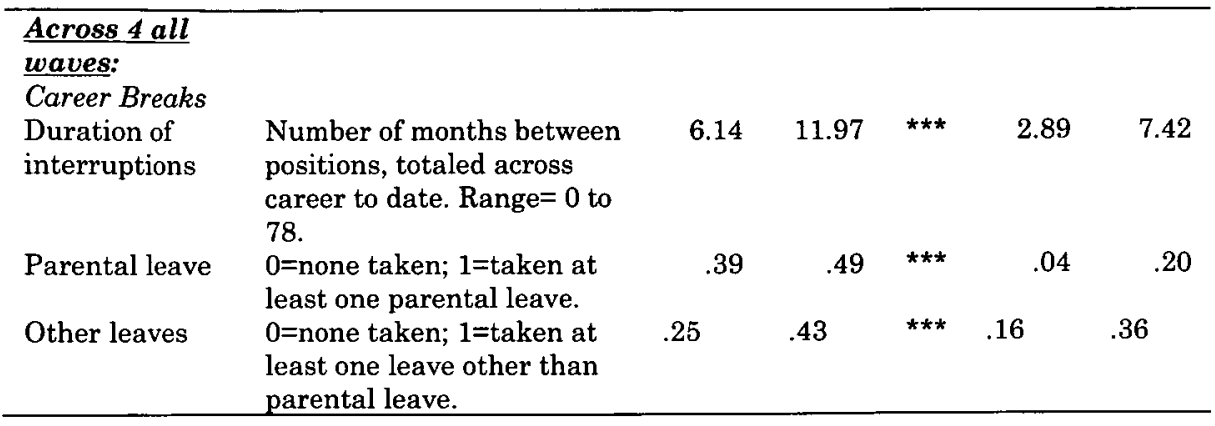

$+p=.06 ;{ }^{*} p<0.05 ;{ }^{* *} p<0.01 ;{ }^{* *} p<0.001$ (two-tailed tests).

Our analysis estimates proportional hazard models using Cox regression. ${ }^{94}$ This procedure allows us to estimate the probability of temporary or permanent departure from private law practice, conditioned on surviving in private practice until the time of observation. ${ }^{95}$ The focus is on the hazard rate or risk of an event occurring - in this case, the event of leaving private practice. Each lawyer's hazard rate for experiencing a transition out of private practice will vary depending on their conditions and can be understood as influencing the expected length of time until the transition occurs. ${ }^{96}$ The model on which this method is based is called a proportional hazards model because the hazard for any one individual is a "fixed proportion of the hazard" for any other individual. ${ }^{97}$ Therefore, variables with coefficients indicated as statistically significant can be interpreted as having a significant effect on the relative timing of exit from private practice, rather than simply whether or not a lawyer exits private practice. ${ }^{98}$

In our analysis, we nest regression models to examine the utility of various explanations for gender differences in leaving private practice.

94. Cox regression offers "the ability to estimate [coefficients] without assuming a particular functional form for the baseline hazard[.] [This] is an important advantage over a more restrictive specification such as the Weibull (which assumes monotonicity through the log transformation)" and such a "model is not well suited to data with interval observations on duration[." Spurr \& Sueyoshi, supra note 1, at 826.

95. See Anne E. Preston, Leaving Science: Occupational Exit From Scientific CAREERS 26-27 (2004).

96. Lisa A. Kramer \& Ellen C. Berg, A Survival Analysis of Timing of Entry into Prostitution: The Differential Impact of Race, Educational Level, and Childhood/Adolescent Risk Factors, 73 Soc. InqUIRY 511, 517 (2003). See also PAUL D. ALlison, SURVIVAL ANALYSIS USING THE SAS System: A PRACTICAL GUIDE (1995).

97. ALLISON, supra note 96, at 114.

98. Kramer \& Berg, supra note 96 , at 518. 
The baseline model shows the effect of demographic and family size variables on leaving private practice. In subsequent models, we add human capital attributes (Model 2), organizational context (Model 3), job satisfaction and experience variables (Model 4), and interruptions and leaves (Model 5). This process of nesting regression models enables us to see which theoretical explanation best accounts for the relationship between gender and leaving private practice. ${ }^{99}$ We turn next to examine the findings from our statistical analysis.

\section{QUANTITATIVE RESULTS}

Among our full sample of 1,577 law graduates, the majority launched their careers in the private practice of law (72 percent). Within private practice, 80 percent entered law firms as associates. Nine percent of the lawyers in private practice started as partners, establishing firms with colleagues or joining an existing practitioner in partnership. Meanwhile, 11 percent began their careers working as solo practitioners. While nearly three-quarters of law graduates entered private practice, other law graduates began their careers in various lines of work. About 10 percent of law graduates entered government, 4 percent worked as in-house counsel for corporations, 2 percent joined Legal Aid or law clinics, and 7 percent worked in other settings. An additional 5 percent of law graduates did not practice law immediately after their admission to the Bar. Our focus is on the pathways for those who started in private practice as law firm lawyers or as solo practitioners.

One of the most interesting observations is just how much mobility there is within legal careers. The lawyers in this study were admitted to the Bar between nineteen and thirty-four years ago (at the time of the 2009 survey). This fifteen-year cohort of lawyers is now in the mid- to late-career stages. Those who started their careers in private practice had on average three professional positions across their careers to date. There is, however, considerable variation. Only 24 percent of the sample had just three positions. Six percent had stayed in the position where they launched their career (many of these are solo practitioners), another 25 percent had two positions, 17 percent had four positions, and 19 percent had five or more professional positions. Another 7 percent had between six and as many as twelve positions over the course of their career.

99. Dryfhout \& Estes, supra note 23, at 118. See generally CAROL S. ANESHENSEL, THEORY-BASED DATA ANALYSIS FOR THE SOCIAL SCIENCES (2002). 
Careers are not necessarily continuous flows from one professional position to another. Many lawyers in our sample of private practitioners had experienced at least temporary interruptions over the course of their careers. Almost half (49 percent) of all private practitioners experienced gaps of some duration between professional positions. The average length of time accumulated across gaps was greater for women (mean=6.14, $\mathrm{SD}=11.97)$ than for men (mean=2.89, $\mathrm{SD}=7.42)$ $(t$-test $=5.47, p<.001)$.

The reasons for career interruptions vary by gender. For women, caring for children was the most common reason (ranging from 25 to 46 percent) for career interruptions. On the other hand, men offered unemployment, higher education pursuits, and travel as reasons why their careers were interrupted. Illness and injury were the least common reasons (typically under 5 percent) for both men and women. Women were consistently more likely than men to list responsibilities for childcare and looking after parents as activities during career interruptions.

Surprisingly, a sizeable share of lawyers left private practice during their careers. Of the 1,134 lawyers starting out careers in private practice, 493 (or 44 percent) left private practice at some point.100 Twenty-five percent exited within four and a half years, and almost half of the lawyers had left private practice within twenty-one years of their admission to the Bar. Women were more prevalent among the departed. Fifty-two percent of women who started in private practice exited, compared with 35 percent of men. Among those lawyers who left private practice, 18 percent of women and 15 percent of men returned to private practice at a later time in their career. We are interested in learning more about these lawyers who left private practice. We explore the factors influencing this exodus in the next section.

Table 2 presents the multivariate results of our Cox proportional hazards regression analysis predicting exits from private practice. These coefficients can be converted to hazard ratios by exponentiating individual coefficients. In most cases, the hazard ratio is easily interpreted as the relative shift in the hazard rate that is associated with a one-unit change in the variable. ${ }^{101}$ For example, according to

100. Some of this movement may be for reasons of retirement, though the majority of our sample would be in their mid-career stage at the time of the survey. The longest career possible in our sample is thirty-four years at the time of the 2009 survey (for a lawyer called to the Bar in 1975), and only a quarter (twenty-four percent) of our sample was over fifty-five years of age at the time of the final survey. It is likely that a small percentage have taken early retirement (though some may have exited law to pursue other careers or business ventures prior to formal retirement).

101. See Mario Cleves et al., AN Introduction to SuRvival ANalysis Using Stata 131 (2d ed. 2008). 
Model 1, women are significantly more likely to leave private practice $\left(\beta=.518^{* * *}\right.$, hazard ratio=1.678). In this case, women face a hazard of leaving private practice that is 68 percent greater than that of men. Generally, a hazard ratio of greater than one suggests an increased risk (probability and timing combined) of attrition, while a ratio of less than one indicates a reduced risk." 102 Having children does not appear to be central to job moves, though something interesting happens when lawyers have three children. There is a significant effect at three children $\left(\beta=.393^{* *}\right.$, hazard ratio=1.481) (providing support for Hypothesis 2). Lawyers with three children move out of private practice 48 percent more quickly than those with no children. This is perhaps a breaking point for firms. As one lawyer in our study commented, "Bay Street has a tolerance for up to two kids. After two kids, women are shown the door."

Model 2 adds human capital effects. Those lawyers working in the area of people law are less likely to make an exit from private practice $\left(\beta=-.483^{*}\right)$ than those in other areas of law. Not surprisingly, lawyers who are successful early in their career at recruiting clients $\left(\beta=-1.364^{* * *}\right)$ and who represent corporate clients $\left(\beta=-1.400^{* * *}\right)$ are also at less of a risk of leaving private practice. It is important here to note that women were less likely to have primary responsibility for bringing in new clients to the firm, and women also spent less time, on average, representing corporate clients than their male colleagues (see Table 1). As a result, the gender difference was reduced with the inclusion of these variables, though the difference remains sizeable and statistically significant $\left(\beta=.339^{*}\right)$.

Inclusion of characteristics of the organizational setting in which lawyers launched their careers did little to reduce the gender gap in leaving private practice. In Model 3, firm size and solo practice settings did not significantly affect the risk of exiting private practice. However, lawyers who successfully landed the job they ideally wanted after law school were less likely to leave private practice at a later date $\left(\beta=-.227^{\star * *}\right)$. Starting off in a much desired job reduces the risk of leaving private practice by 21 percent. The matching of aspired position with eventual job offer is a powerful retainer of legal talent. Yet, for those who entered private practice during periods of economic hardship-many lawyers in our sample were among the graduates entering law during the recession of the late 1980s--poor economic climate was a significant force, over and above their human capital and

102. Jennifer Imazeki, Teacher Salaries and Teacher Attrition, 24 ECON. EDUC. REv. 431,438 (2005). 
organizational context, that pushed them out of private practice $\left(\beta=.064^{*}\right)$ (consistent with Hypothesis 5 ).

In Model 4, we introduce job satisfaction and experience measures. Satisfaction with power-track proves to be an important element in reducing lawyers' risk of leaving private practice ( $\left.\beta=-.324^{* * *}\right)$. Consistent with Hypothesis $1 \mathrm{~b}$, individuals starting out in environments rich with promotional and financial opportunities move 28 percent more slowly out of private practice than individuals working in different environments. In contrast, satisfaction with content of legal work does not have the same holding power. Counter to Hypothesis 1a, satisfaction with content of legal work increases the risk of leaving private practice $\left(\beta=.197^{* *}\right)$. Lawyers who are more satisfied with the content of their legal work move out of private practice 22 percent more quickly than those less satisfied. Perhaps satisfaction with legal work is merely portable to other sectors of law that are outside private practice but still within the profession. Furthermore, satisfaction with collegiality in the workplace does not ensure that lawyers will stay in private practice (counter to Hypothesis 1c). Satisfaction with collegiality increases the risk of leaving private practice $\left(\beta=.142^{*}\right)$. Lawyers experiencing more collegial workplaces move out of private practice 15 percent more quickly than those less satisfied with their coworkers. It seems that enjoying the substance of law practice and having good colleagues may not be sufficient to keep lawyers in private practice when other factors fall short of expectations.

In sharp contrast, workplaces that offered flexible schedules (on a full-time basis) significantly decreased the risk of lawyers leaving private practice $\left(\beta=-.218^{*}\right)$. Consistent with Hypothesis 3 , lawyers working in offices that offered flexible full-time schedules moved out of private practice 20 percent more slowly than those without flexible schedules. Such flexibility, while still maintaining full-time hours, might be a much-valued benefit for lawyers with family responsibilities or those lawyers seeking to attain an improved quality of life.

In Model 4, we also introduced a measure of sexual discrimination experiences in the practice of law. Lawyers who experienced discrimination were significantly more likely to exit $\left(\beta=.257^{*}\right)$, leaving private practice 29 percent more quickly than those who were not targeted by sexual discrimination. This experience was highly gendered, with 74 percent of women in our sample reporting having experienced sexual discrimination in the practice of law, while only 11 percent of men stated they had experienced sexual discrimination. With the introduction of sexual discrimination to our equation, gender is no longer a significant predictor of the risk of leaving private practice. 
In our final model, Model 5, we introduce the effects of interruptions on careers. Parental leave has the largest effect $\left(\beta=.337^{* *}\right)$. Taking a parental leave moves individuals out of private practice 40 percent more quickly. Thirty-nine percent of women in private practice reported taking a parental leave compared with just 4 percent of men $(t$-test $=15.997, p<.001)$. Leaves for other reasons also propel lawyers out of private practice $\left(\beta=.263^{*}\right)$. These other leaves move lawyers out of private practice 30 percent more quickly than those who have not taken such leaves. Again, these leaves were more often taken by women $(25$ percent) than men (16 percent) $(t$-test $=4.035, p<.001)$. In addition, consistent with Hypothesis 4a, longer interruptions between professional positions also appear to move lawyers out of private practice more quickly $\left(\beta=.014^{\star * *}\right)$. Recall that these leaves were for a range of reasons, including unemployment spells, return to education, travel, illness or injury, and care of children. That said, women were more likely to experience these interruptions, often for the care of children. 
Table 2. Cox Proportional Hazard Estimates of Leaving Private Practice $(N=1,134)$

\begin{tabular}{|c|c|c|c|c|c|}
\hline & $\begin{array}{c}\text { Model } 1 \\
\beta\end{array}$ & $\begin{array}{c}\text { Model } 2 \\
\beta\end{array}$ & $\begin{array}{c}\text { Model } 3 \\
\beta \\
\end{array}$ & $\begin{array}{c}\text { Model } 4 \\
\beta\end{array}$ & $\begin{array}{c}\text { Model } 5 \\
\beta \\
\end{array}$ \\
\hline \multicolumn{6}{|l|}{$\begin{array}{l}\text { Demographics } \\
\text { \& Family }\end{array}$} \\
\hline Gender & $.518^{* * *}$ & $.339^{*}$ & $.385^{* * *}$ & .173 & .066 \\
\hline $\begin{array}{l}\text { Racial } \\
\text { minority }\end{array}$ & .172 & .178 & .131 & .102 & .062 \\
\hline $\begin{array}{l}\text { Married } \\
\text { Children: a }\end{array}$ & -.056 & .029 & .084 & .120 & .084 \\
\hline 1 child & .181 & .259 & .263 & .207 & .111 \\
\hline 2 children & .101 & .234 & .256 & .178 & .038 \\
\hline 3 children & $.393^{\star *}$ & $.378^{*}$ & $.457^{\star *}$ & $.339 *$ & .238 \\
\hline $4+$ children & -.013 & .048 & .046 & -.052 & -.187 \\
\hline \multicolumn{6}{|l|}{ Human } \\
\hline $\begin{array}{l}\text { Elite law } \\
\text { school }\end{array}$ & & -.076 & -.010 & -.072 & -.090 \\
\hline \multicolumn{6}{|l|}{ Areas of law: } \\
\hline Business law & & -.211 & -.102 & -.078 & -.079 \\
\hline Litigation & & -.304 & -.263 & -.224 & -.226 \\
\hline People law & & $-.483^{*}$ & $-.506^{* *}$ & $-.442^{*}$ & $-.405^{*}$ \\
\hline Criminal law & & -.098 & -.043 & .102 & .127 \\
\hline $\begin{array}{l}\text { Hours per } \\
\text { week }\end{array}$ & & .004 & .005 & .004 & .005 \\
\hline $\begin{array}{l}\text { Client } \\
\text { recruitment }\end{array}$ & & $-1.364^{* * *}$ & $-1.349 * * *$ & $-1.362^{* * *}$ & $-1.286^{* * *}$ \\
\hline $\begin{array}{l}\text { Corporate } \\
\text { clients }\end{array}$ & & $-1.400^{* * *}$ & $-1.347^{* * *}$ & $-1.277 * * *$ & $-1.240^{* * *}$ \\
\hline \multicolumn{6}{|l|}{ Organizational } \\
\hline Solo practice & & & .354 & .350 & .339 \\
\hline Small firm & & & .302 & .294 & 280 \\
\hline $\begin{array}{l}\text { Large } \\
\text { mid-sized firm }\end{array}$ & & & .303 & .301 & .306 \\
\hline Large firm & & & .080 & .147 & .181 \\
\hline $\begin{array}{l}\text { Landed first } \\
\text { job desired }\end{array}$ & & & $-.227^{* * *}$ & $-.204^{* * *}$ & $-.194^{* * *}$ \\
\hline
\end{tabular}




\begin{tabular}{lccc}
\hline $\begin{array}{l}\text { Greater } \\
\text { Toronto Area } \\
\text { Unemployment } \\
\text { rate at call }\end{array}$ & .139 & .138 & .120 \\
& $.064^{*}$ & .053 & .053 \\
$\begin{array}{l}\text { Satisfaction \& } \\
\text { Experiences }\end{array}$ & & & \\
Satisfaction: & & & \\
$\quad$ Content of & & $.197^{* * *}$ & $.196^{* * *}$ \\
work & & \\
$\quad \begin{array}{l}\text { Power-track } \\
\text { Collegiality }\end{array}$ & $-.324^{* * *}$ & $-.343^{* * *}$ \\
Flexible hours & $.142^{* *}$ & $.152^{* *}$ \\
Discrimination & $-.218^{*}$ & -.182 \\
Career Breaks & $.257^{*}$ & .134 \\
$\begin{array}{l}\text { Duration of } \\
\text { interruptions }\end{array}$ & & $.014^{* * *}$ \\
Parental leave & & $.337^{* *}$ \\
Other leaves & & $.263^{*}$ \\
\hline
\end{tabular}

aNo children is the comparison category.

bSmall mid-sized firm is the comparison category.

${ }^{*} p<0.05 ;{ }^{* *} p<0.01 ;{ }^{* * *} p<0.001$ (two-tailed tests).

In Table 3, we examine these models separately for men and women. Some interesting gender differences emerge. First, the effects of having children on legal careers vary dramatically for women and men. When we explore the reduced model (Model 1) separately for women and men, we discover men's hazard of leaving private practice decreases by 42 percent with two children (hazard ratio $=.579, p<.01$ ) and by 53 percent with four or more children (hazard ratio $=.466, p<.05$ ). In contrast, women's hazard rate for leaving private practice increases by 53 percent with one child (hazard ratio $=1.526, p<.05$ ), 69 percent with two children (hazard ratio $=1.69, p<.01$ ), and 106 percent with three children (hazard ratio $=2.063, p<.001$ ). The effects of the number of children fell from statistical significance with the introduction of the parental leave variable, suggesting that parental leave mediates the relationship between children and leaving private practice.

Working long hours increases the hazard for women to leave private practice, but it had no similar effect on men's movement out of private practice. Recruiting clients to the firm and serving corporate clients 
both assure women and men of a reduced risk of leaving private practice, though the effects were stronger for men. Women appear to move out of small firms of less than ten lawyers more quickly $(p<.05)$, while men's retention rate appears more secure in the large law firms (borderline significance of $p<.10$ ).

Counter to Hypothesis $1 \mathrm{~d}$, we find no statistically significant differences in men's and women's mean average levels of satisfaction across content of work, power-track, and collegiality (See Table 1). Satisfaction with power-track was particularly effective in stemming the flow from private practice, and this effect was significantly stronger for men. And interestingly, although the effect of flexible (full-time) hours is negative on the movement of men and women out of private practice, this effect is statistically significant only for men. The provision of flexible, full-time work appears to be of considerable value to male lawyers.

Perhaps most impressive are the effects of leaves. Women pay a heavy price for both parental leaves and any other forms of leave taken during their positions in private practice. Taking a parental leave increases women's hazard of leaving private practice by 37 percent (hazard ratio $=1.370, p<.05$ ) and taking a leave for other purposes augments the hazard of leaving by 48 percent (hazard ratio $=1.486$, $p<.01$ ) (supporting Hypothesis $4 \mathrm{~b}$ ). In sharp contrast, for men, taking a leave, parental or otherwise, has no significant impact on their risk of leaving private practice. 
Table 3. Cox Proportional Hazard Estimates of Leaving Private Practice, Men and Women Separately

\begin{tabular}{|c|c|c|c|c|}
\hline & \multicolumn{2}{|c|}{$\operatorname{Men}(N=558)$} & \multicolumn{2}{|c|}{ Women $(N=576)$} \\
\hline & $\begin{array}{l}\text { Baseline } \\
\text { Model }\end{array}$ & Full Model & $\begin{array}{l}\text { Baseline } \\
\text { Model }\end{array}$ & $\begin{array}{c}\text { Full } \\
\text { Model }\end{array}$ \\
\hline & $\beta$ & $\bar{\beta}$ & $\beta$ & $\beta$ \\
\hline $\begin{array}{l}\text { Demographics } \\
\text { \& Family }\end{array}$ & & & & \\
\hline Racial & .022 & .069 & .228 & .081 \\
\hline minority & .255 & .130 & -.254 & .075 \\
\hline Married & & & & \\
\hline Children: ${ }^{a}$ & -.238 & .054 & $.422^{\star}$ & .085 \\
\hline 1 child & $-.546^{*}$ & .073 & $.525 *$ & .126 \\
\hline 2 children & -.126 & .335 & $.724 * * *$ & .307 \\
\hline $\begin{array}{l}3 \text { children } \\
4+\text { children }\end{array}$ & $-.764^{*}$ & -.299 & .432 & -.023 \\
\hline $\begin{array}{l}\text { Human } \\
\text { Capital }\end{array}$ & & .099 & & -.238 \\
\hline Elite law & & -.553 & & .157 \\
\hline school & & -.308 & & -.211 \\
\hline Areas of law: & & $-.547+$ & & -.384 \\
\hline Business law & & .148 & & -.076 \\
\hline Litigation & & .002 & & $.009+$ \\
\hline People law & & & & \\
\hline Criminal law & & $-1.710^{* * *}$ & & $-.974 * * *$ \\
\hline $\begin{array}{l}\text { Hours per } \\
\text { week }\end{array}$ & & $-1.378^{* * *}$ & & $-1.119^{* * *}$ \\
\hline $\begin{array}{l}\text { Client } \\
\text { recruitment }\end{array}$ & & & & \\
\hline Corporate & & .164 & & $.495+$ \\
\hline clients & & $\begin{array}{r}-.076 \\
.441\end{array}$ & & $\begin{array}{l}.474^{*} \\
.243\end{array}$ \\
\hline Organizational & & & & \\
\hline Settingb & & $.478+$ & & -.066 \\
\hline $\begin{array}{l}\text { Solo practice } \\
\text { Small firm }\end{array}$ & & $-.173^{* *}$ & & $-.202^{* * *}$ \\
\hline $\begin{array}{l}\text { Large } \\
\text { mid-sized firm }\end{array}$ & & .114 & & .156 \\
\hline $\begin{array}{l}\text { Large firm } \\
\text { Landed first }\end{array}$ & & .074 & & .019 \\
\hline
\end{tabular}




\begin{tabular}{|c|c|c|}
\hline job desired & & \\
\hline Greater & & \\
\hline Toronto Area & & \\
\hline Unemployment & & \\
\hline rate at call & $.306^{* * *}$ & $.124^{*}$ \\
\hline & $-.420 * * *$ & $-.346^{* * *}$ \\
\hline Satisfaction \& & $.168^{\star}$ & $.149^{*}$ \\
\hline Experiences & $-.418^{*}$ & -.056 \\
\hline Satisfaction: & -.054 & .129 \\
\hline $\begin{array}{l}\text { Content of } \\
\text { work }\end{array}$ & & \\
\hline Power-track & $.035 * * *$ & $.008+$ \\
\hline Collegiality & & \\
\hline Flexible hours & .340 & $.315^{*}$ \\
\hline Discrimination & -.038 & $.396^{* *}$ \\
\hline Career Breaks & & \\
\hline Duration of & & \\
\hline interruptions & & \\
\hline Parental leave & & \\
\hline Other leaves & & \\
\hline
\end{tabular}

a No children is the comparison category.

bSmall mid-sized firm is the comparison category.

${ }^{*} p<0.05 ;{ }^{* *} p<0.01 ;{ }^{* * *} p<0.001$ (two-tailed tests).

\section{DISCUSSION AND CONCLUSION}

This paper began with an exploration of three theoretical models of turnover. Our study found mixed support for the role of job satisfaction. Although, satisfaction with power-track (promotions, earnings, and prestige) reduced the risk of lawyers leaving private practice, satisfaction with content of work and collegiality did not have the same retention power. Our measures of job satisfaction were derived from the first survey in 1990 and serve only as a proxy for facets of job satisfaction in early careers. It is possible that many lawyers shifted jobs early on in an attempt to achieve better levels of job satisfaction. We found no evidence of gender differences across facets of job satisfaction, although satisfaction with power-track appears more effective at retaining men than women lawyers in private practice.

We also explored the role of family pressures. We found evidence that women are at a greater risk of leaving private practice, especially when they have more than one child, while men are more likely to 
remain in private practice with growing families. However, it is the impact of parental and other leaves and interruptions between professional positions that take the greatest toll on women's careers. Upon return from these relatively short gaps (over the course of a career), women lawyers appear to face an uphill battle with retention and advancement in private practice. A key issue is to investigate how women are treated upon return from parental leaves and whether they are disadvantaged in terms of clientele, assignments, support by colleagues, and assessments of competence by firm leaders. Are women, as some research suggests, held to a higher standard than their male colleagues upon their return from a parental leave? ${ }^{103}$

\section{A. Nature and Time of Exits}

An important question is whether lawyers who leave private practice do so as a result of their own decision to quit or as a result of layoffs, firing, or other forms of termination? Several studies find that employees quit jobs sometimes as a preemptive move when employees perceive a high risk of job loss. ${ }^{104}$ Early exits from private practice may be the result of associates leaving their firm in anticipation of not receiving an invitation to join the firm's partnership. ${ }^{105}$ It seems, however, more likely that such early job changes would lead associates to seek positions with other firms or to establish a solo practice, enabling them to continue in their areas of law and within private practice rather than exiting private practice altogether.

Unfortunately, our study does not enable us to distinguish between voluntary (e.g. quits) and involuntary turnover (e.g. termination). On the one hand, having knowledge of the specific context under which a

103. See, e.g., Kay \& Hagan, supra note 1 , at 1 ("Female lawyers participate fully in the accumulation of social capital in law firms, through service to valued institutional clientele and high billings, yet their efforts result in reduced probabilities of partnership.").

104. Moen et al., supra note 34, at 73. See, e.g., Rosemary Batt \& P. Monique Valcour, Human Resources Practices as Predictors of Work-Family Outcomes and Employee Turnover, 42 INDUS. REL. 189, 212 (2003) ("Job security tend[s] to decrease turnover intentions"); Charles F. Manski \& John D. Straub, Worker Perceptions of Job Insecurity in the Mid-1990s: Evidence from the Survey of Economic Expectations, 35 J. HUM. RESOURCES 447, 467 (2000) ("A voluntary quit may occur when a worker anticipates future job loss and decides that it is preferable to separate sooner.").

105. See Gorman, supra note 88, at 638 ("[F]irm partners consider the associate for admission to the firm's partnership. If the associate is 'passed over,' or rejected, he or she is expected to leave the firm within a reasonable period of time."). 
job exit took place may be relevant to subsequent job moves, ${ }^{106}$ and these different types of exits may have different antecedent factors. ${ }^{107}$ However, current scholarship suggests that "[i]n a climate of rising risk and constraint, voluntary-involuntary turnover distinctions are increasingly blurred."108 Some women or men exit their jobs (and private practice) because of parenting obligations and poor work-life balance, while others quit in anticipation of being let go or are encouraged to leave voluntarily. Lawyers may describe their moves as voluntary when in fact termination was imminent or had already taken place. ${ }^{109}$

Regardless of whether exits were voluntary, some research suggests women are departing firms "in large numbers prior to making partner."110 Mary Noonan and Mary Corcoran, for example, found "[w]omen who entered private practice were 1.8 times as likely as men to leave within four years (18 versus 10 percent)."111 Our findings suggest this form of attrition is an important part of the story. Women in our sample were more likely to leave private practice early in their careers: 31 percent of women compared with 21 percent of men left within five years $(t$-test $=-7.40, p<.001)$. Our results also suggest that many moves from private practice take place after lawyers have already attained law firm partnership status. Studies have suggested that some women delay having children until after they have reached partnership.112 Having established themselves within firms, these women then encounter the full weight of an organizational structure that lacks accommodation for parental leaves and schedule flexibility. A study more narrowly focused on exits from law firms could more directly address whether, prior to partnership decisions, women switch firms or leave private practice and whether different or similar dynamics drive women out after partnership has been granted.

106. Blair Wheaton \& Sarah Reid, The Role of Timing us. Duration in the Cumulative Work History Effects of Job Exits and Nonemployment on Women's Mental Health, 13 ADVANCES LIFE COURSE RES. 195, 226 (2008).

107. See Park \& Sandefur, supra note 82 (examining racial and ethnic differences in quits and reasons for quits among men).

108. Moen et al., supra note 34 , at 74 .

109. See Park \& Sandefur, supra note 82 (discussing racial and ethnic disparities in voluntary and involuntary moves).

110. Reichman \& Sterling, supra note 1, at 962.

111. Noonan \& Corcoran, supra note 1 , at 146.

112. See LEIPER, supra note 10, at 103-142. 


\section{B. Policy and Practice}

Firms offer earnings and promotions as inducements to retain their professional legal talent who might otherwise easily transfer to other firms. ${ }^{113}$ Our study suggests that satisfaction with power-track reduces the risk that lawyers will leave private practice. Nonetheless, firms can take other initiatives to retain legal talent, initiatives that are less costly than lucrative salaries. Lawyers in our study were less likely to leave organizations that offered flexible full-time hours. This finding is consistent with a sizeable body of research demonstrating that greater employee flexibility can promote retention, especially for employees with chronic overloads and time strains. ${ }^{114}$ Pamela Stone's research has shown that women professionals often feel pushed out precisely because of the inflexibility and excessive demands of their jobs. ${ }^{115}$ Unfortunately, flexibility policies are often "on the books" but not widely available in practice. ${ }^{116}$ Scholars increasingly suggest more fundamental changes are needed to the structure and culture of time at work to achieve improved well-being of professionals and their families. ${ }^{117}$ This will require fundamental changes to the temporal organization of work,

113. See Saporta \& Farjoun, supra note 20, at 263.

114. See, e.g., Armstrong et al., supra note 21, at 150 ("The tension created by the need for a flexible work schedule can adversely impact a woman's promotional opportunities and lead to voluntary turnover."); E. Jeffrey Hill et al., Researching the 60-Hour Dual-Earner Workweek: An Alternative to "Opt-Out Revolution," 49 AM. BEHAV. SCIENTIST 1184, 1198 (2006) ("[T] he 60-hour workweek, especially when coupled with flexibility . . . may ... aid couples in reaching a satisfying balance that does not require them to . . opt out of their chosen professions."). See generally Erin L. Kelly \& Phyllis Moen, Rethinking the Clockwork of Work: Why Schedule Control May Pay Off at Work and at Home, 9 ADVANCES DEVELOPING HuM. RESOURCES 487 (2007) (discussing the benefits of schedule control).

115. See STONE, supra note 34 , at 18-19.

116. See Kelly \& Moen, supra note 114, at 489-90. See generally Scott Schieman \& Paul Glavin, Trouble at the Border?: Gender, Flexibility at Work, and the Work-Home Interface, 55 SOC. PROBS. 590 (2008) (examining "the effects of schedule control and job autonomy on two forms of work-home role blurring: receiving work-related contact outside of normal work hours and bringing work home.").

117. See Moen, supra note 34 , at 70. See, e.g., Suzanne M. Blanchi ET AL., Work, FAMILY, HEALTH, AND WELl-BEING (2005); IT'S ABOUT TIME: CoUples AND CAREERS (Phyllis Moen ed., 2003); THE WORK AND FAMILY HANDBOoK: MULTI-Disciplinary Perspectives, Methods, AND Approaches (Marcie Pitt-Catsouphes et al. eds., 2006); WORK AND LIFE INTEGRATION: ORGanizational, CUlTural, AND INDIVIdUAL PERsPeCtives (Ellen Ernst Kossek \& Susan J. Lambert eds., 2005); Erin L. Kelly et al., Getting There From Here: Research on the Effects of Work-Family Initiatives on Work-Family Conflict and Business Outcomes, 2 ACAD. MGMT. ANNALs 305, 314-15 (2008); Kelly \& Moen, supra note 114, at 1 (describing "limitations of flexible work policies, propos[ing] a conceptual model of how schedule control impacts work-life conflicts, and describ[ing] specific ways to increase employees' schedule control"). 
more than simply drafting policies that are frowned upon by firm management if accessed by lawyers. ${ }^{118}$

Another strategy to retain legal talent is to offer improved parental leave arrangements. Our results suggest that perceptions of sexual discrimination may be connected to the negative career consequences of taking parental and other leaves. Women who take a parental leave may find themselves marginalized in the firm upon their return. ${ }^{119}$ Future research should explore the impact of length of parental leave and the consequences of taking more than one parental leave on promotions and retention in law firms. Parental leaves may be particularly restricted within solo practice and small firms for financial reasons, and it is notable that we find women are at greater risk of leaving private practice from small firms. Programs that provide financial benefits to practicing lawyers in small firms and solo practices may help to make parental leaves a realistic option, while maintaining the viability of these smaller practices. ${ }^{120}$

The need for greater balance between professional and private life in the legal profession has been the subject of considerable discussion in recent years in the media, law journals, and legal periodicals. ${ }^{121}$

118. Moen et al., supra note 34 , at 70 .

119. See Cynthia Fuchs Epstein et al., Glass Ceilings and Open Doors: Women's Advancement in the Legal Profession, 64 FordHaM L. REv. 291, 420-21 (1995) (discussing the importance of collegial support for parental leaves).

120. Recently, the Law Society of Upper Canada (Ontario) extended its three-year pilot "Parental Leave Assistance Program" (PLAP), though the program came under heated debate recently. Maureen Brosnahan, Ontario Law Society Poised to Drop Parental Leave Program, CBC NEws (Nov. 21, 2012 1:32 PM), http://www.cbc.ca/news/canada/toronto/ story/2012/11/21/law-society-ontario-parental-leave-program.html; Yamri Taddese, LSUC Likely to Axe Parental Leave Benefits, Legal FeEdS (Nov. 16, 2012), http://www.canadian lawyermag.com/legalfeeds/lsuc-likely-to-axe-parental-leave-benefits.html. The goal of this pilot program is to reduce the hardship that arises when a practicing lawyer who is a partner in a small firm or a solo practitioner takes parental leave. The program provides financial benefits to practicing lawyers in firms of five lawyers or fewer who do not have access to other maternity, parental, or adoption financial benefits under public or private plans and who meet the eligibility criteria. The Parental Leave Assistance Program is a recommendation developed by the Law Society's Retention of Women Working Group. Notice to the Profession-Changes to the Parental Leave Assistance Program, THE LAW SOCIETY OF UPPER CANADA, http://www.lsuc.on.ca/with.aspx?id=2147487024 (last visited Apr. 28, 2013).

121. See, e.g., Trish Crawford, Women Lawyers Leaving in Droves, TORONTO STAR (Feb. 25, 2011), http://www.thestar.com/living/article/944937--women-lawyers-leaving-in-droves; Jeff Gray, Why Supermom is Leaving the Law Firm, THE GLOBE AND MAIL (Nov. 8, 2011, 6:27 PM), http://www.theglobeandmail.com/report-on-business/industry-news/the-lawpage/why-supermom-is-leaving-the-law-firm/article4251445/; Neal McLennan, Women Lawyers \& the Boys' Club, BC BusINESS (June 9, 2010), http://www.bcbusinessonline.ca/ bcb/top-stories/2010/06/09/women-lawyers-amp-boys039-club; Kelly Pullen, The Problem with Women, TORONTO LIFE (May 10, 2010 11:30 AM), http://www.torontolife.com/daily 
Numerous studies have called for alterations in the structure of the profession to allow greater flexibility in scheduling, taking leaves, ${ }^{122}$ and easier transiting for those who want to leave the profession and reenter at a later time. ${ }^{123}$

Improving flexibility for lawyers in private practice and accessibility for individuals returning to private practice are pressing issues, particularly given changes to legal careers brought on by the forces of globalization, economic recession, and the growth and reach of large law firms. For legal professionals, turnover is rapidly becoming a fact of contemporary working life, as job changes and job insecurity become the norm. The career mystique of continuous employment with the same firm is no longer the case. ${ }^{124}$ As Phyllis Moen and colleagues remark, "Contemporary employment paths are often marked by turnover in light of global economic forces and job conditions impelling employees out of particular jobs and even out of the workforce."125 Our study reveals career interruptions between professional positions in private practice may hasten lawyers' exits from private practice. Future research needs to examine the nature of those interruptions. Some studies suggest that unemployment spells might be more damaging to future earnings than gaps for self-employment or family leave.126 Future work needs to explore whether gaps between professional positions and leaves during positions, and for which purposes, are viewed as resulting in skill

/informer/from-print-edition-informer/2010/05/10/the-problem-with-women/; Karen Selick, Don't Lower the Bar, National PosT (Canada), Aug. 22, 2007, at A17; Anne-Marie Slaughter, Why Women Still Can't Have It All, ATLANTIC (June 13, 2012 10:15 AM), http://www.theatlantic.com/magazine/archive/2012/07/why-women-still-cant-have-itall/309020/; Janice Tibbetts, Female Lawyers Forced to Ditch Careers; Total Workload Behind Exodus, Top Judge Says, OTTAWA Citizen, Aug. 15, 2007, at A7.

122. See, e.g., THE LAW SOc'y OF UPPER CAN., Final REPORT-RETENTION OF WOMEN IN Private Practice Working Group 9 (2008) (calling for law firms to develop "maternity/parental leaves and flexible work arrangements"); Reichman \& Sterling, supra note 1, at 962 ("These changes will need to include ... greater flexibility in scheduling and the ability to take leave[] from work.").

123. See generally Timothy L. O'Brien, Why Do So Few Women Reach the Top of Big Law Firms?, N.Y. TIMES (Mar. 19, 2006), http://www.nytimes.com/2006/03/19/business/ yourmoney/19law.html? pagewanted=all\&_r=0.

124. See Moen \& Roenling, supra note 9, at 8-18 (describing the career mystique and its origins).

125. Moen et al., supra note 34 , at 69.

126. See, e.g., Donald Bruce \& Herbert J. Schuetze, The Labor Market Consequences of Experience in Self-Employment, 11 LAB. ECON. 575, 596 (2004) ("[T] he negative labor market consequences associated with unemployment spells ... are more severe than those associated with self-employment."); Gert Theunissen et al., Career Sidestep, Wage Setback? The Impact of Different Types of Employment Interruptions on Wages, 18 GENDER, WORK \& ORG. e110, e125 (2011) (finding "a wage penalty for unemployment spells and family breaks," but no such penalty for self-employment). 
atrophy and whether these paths have a negative impact on subsequent employment and earnings. ${ }^{127}$

In conclusion, careers among private practitioners appear to be changing through a diversity of pathways, with continuity of employment with one employer no longer the singular career model. Increasingly, lawyers move between firms and across sectors of practice, and these trajectories may include gaps between jobs and leaves during the course of professional positions. Yet, the private practice of law continues to rely on a traditional model of linear and continuous careers, ${ }^{128}$ with an emphasis on billable hours as the "bottom line,"129 and a strong resistance to workplace accommodations. Attrition from private practice appears to be rooted in organizational constraints that push lawyers out. Discussions that focus on work-life balance as exclusively a woman's issue or that focus narrowly on motherhood as the primary source of job-leaving among women lawyers deflect attention from the important structural and institutional issues that constrain career pathways for both men and women in the legal profession. ${ }^{130}$

127. See generally WILLIAMS, supra note 78 ("The central argument of this book is that conventional family life does not work well for those who live it.").

128. Sirianni \& Negrey, supra note 79, at 66. See generally JOAN BROCKMAN, GENDER IN THE Legal Profession: FITTING OR BREAKING THE MOULD (2001).

129. Epstein, supra note 52, at 323; Rhode, supra note 10 , at 1008.

130. Percheski, supra note 12, at 514. See also Wenk \& Rosenfeld, supra note 10, at 129 ("Most of the existing literature on women's employment reentry focuses on one particular reason to the exclusion of others, with a great deal of it on women's employment patterns associated with childbirth."). 